| Araştırma Makalesi / Research Article |

\title{
Görsel Sanatlar Dersi İçin Açık Havada Eğitim Deneyimi ${ }^{1}$
}

\section{Outdoor Education Experience For The Visual Arts Course}

\section{Ceylan Sebik ${ }^{2}$, A.Dilek Kıratlı ${ }^{3}$}

Anahtar Kelimeler
görsel sanatlar öğretimi
görsel sanatlar
öğretmenleri
açık havada eğitim
etkinliği
aktif öğrenme

\section{Keywords}

visual arts teaching

visual arts teachers

outdoor education

activity

active learning

Başvuru Tarihi/Received

17.01.2020

Kabul Tarihi /Accepted

23.06.2020

\section{Öz}

Bu araştırmada, Açık Havada Eğitim (AHE) ile gerçekleştirilen Görsel Sanatlar Dersi'nin uygulama sonuçlarının ortaya konulması amaçlanmıştır. Belirtilen amaç doğrultusunda görsel sanatlar öğretiminin temel öğrenme alanları olan görsel iletişim, görsel eleştiri ve kültürel bilinç bağlamında öğrenme süreci gözlemlenmiştir. Araştırma ortaokul 5. sınıf öğrencileri ile görsel sanatlar dersinde altı hafta süresince gerçekleştirilmiştir. Araştırma kapsamında sekizi odak olmak üzere toplam 21 öğrenci yer almıştır. Nitel araştırma deseni ile çalışılan araştırmada; doküman, gözlem ve görüşme yoluyla toplanan verilerin betimsel analizi sonrasında elde edilen bulgular alanyazın ile ilişkilendirilerek yorumlanmıştır. Araştırmanın bulguları kapsamında elde edilen temalar: Görsel ifade, eleştirel ifade ve kültürel ifade olarak belirlenmiştir. Araştırma bulguları doğrultusunda elde edilen sonuçlara göre Görsel Sanatlar Dersi'nin açık havada eğitim etkinlikleri ile uygulanması sonucunda öğrenme alanları düzeyinde olumlu yansımaları tespit edilmiştir. AHE'yi uygulamak isteyen öğretmenlere deneyime dayalı bir ders örneği sunarak alana katkı sunacağı düşünülmektedir.

\section{Abstract}

In this study, the aim is to reveal the application results of the visual arts course performed with Outdoor Education (AHE). In line with this aim, learning process has been observed within the context of visual communication, visual criticism and cultural awareness, which are the main learning areas of visual arts teaching. The research was performed for six weeks in visual arts course with 5th grade middle school students. A total of 21 students, focused on 8 of them, were included in the study. In the study, which is performed through qualitative research design, the findings obtained after the descriptional analysis of the data collected through documents, observations and interviews, have been associated with the field literature and interpreted. Themes obtained within the context of the findings are: visual expression, critical expression and cultural expression. Positive results of the research findings have been found in the level of learning areas. It is believed that the study will contribute to the field by providing an example of an experience-based course to teachers, who want to apply AHE (Outdoor Education), and by providing resources to a new and interesting topic in national literature.

\footnotetext{
${ }^{1}$ Birinci yazarın Doktora tez çalışmasından türetilmiştir.

${ }^{2}$ Ondokuz Mayıs Üniversitesi, Güzel Sanatlar Fakültesi, Resim Bölümü, Samsun, TÜRKiYE; https://orcid.org/0000-0001-5723-5124

${ }^{3}$ Anadolu Üniversitesi, Eğitim Fakültesi, Güzel Sanatlar Eğitimi Bölümü, Eskişehir, TÜRKiYE; https://orcid.org/0000-0001-6514-9330
} 


\section{Extended Abstract}

\section{Introduction}

In the study, it is aimed to reveal the application results of Visual Arts course that is performed with AHEE. For the aim of the study; The main learning areas in the Visual Arts courses structured by the researcher by AHEE are; Observation in the context of Visual Communication, Visual Criticism and Cultural Consciousness constitute the sub-objectives of the study.

\section{Method}

In this study, case study design was used. The case study covers in-depth and longitudinal analysis of the data obtained and analysed through participant observations by in-depth interviews and document collection (Glesne, 2013, p. 13). According to Akar's (2016, p. 126) status indication process scheme; for macro level depiction, the conceptual framework of AHE and for micro level depiction, the reflections of the application program that is prepared by the researcher on the learning domain were discussed in the study. In the case study, a planned process for explaining the meaning and relationships between data is expressed. Accordingly, the qualitative research structure, in-depth data collection and analysis process is expressed under the title of method. This study was carried out with the participation of total 21 students on the fifth grade of middle school and teachers, eight of which are focused, and one researcher and three external observers (out of field), two internal observers (in field) and two visual recorder officials. Eight of the 21 students who compose the study were determined as focus students. Volunteering was based on for the selection of focus students.

Study Practice Period: In AHEE there are also introduction, development and conclusion chapters for the program. In this context, each course prepared with AHEE takes place in three phases: meeting, implementation and evaluation (Gilbertson et al., 2005, p. 86). Implementations take place in these three phases.

Collection of Data: According to Glesne (2013, p. 63), who emphasized a point that should be considered in the use of multiple data collection techniques in study, multiple data collection is not a technique used to validate data in terms of validity and reliability. Accordingly, externalinternal observers were used to create the data diversity that used in the study. Two undergraduate students from the field of art education were assigned as internal observers. External observers composed of three undergraduate students from science field that using the AHEE. In the study, document analysis (student diaries, observer forms and publications of AHEE implementation examples), semi-structured interviews (teacher and focus students), video recordings and visuals were used as data collection tools.

Data Analyse: At this stage, all the audio and visual sources, including semi-structured interviews, observation notes, diaries and video recordings were textualized by listening and watching repeatedly. Then, the printing process of documents that were transferred to the notebook such as diaries and field notes were completed in digital environment. In the coding phase, which is the first phase of the analysis, the parts that point to the study questions after detailed readings by the researcher and that have emerged as a phenomenon although they have no connection with the research questions are also coded. Then the created code-theme files were examined in detail by a field expert. Accordingly, while the related expressions were gathered under common themes, text / visual, theme and code relations were reviewed. Sub-headings of the themes obtained were created sub-themes. While the themes and sub-themes created were compared and the consensus reached themes remained the same, the diverging sections were rearranged.

\section{Result and Discussion}

Themes obtained within the scope of the study findings: Specified as Visual expression, Critical expression and Cultural expression. Accordingly, sub-themes related to the theme of visual expression were identified as developing creative ideas, communicating, reflecting and imaginary thinking. Sub-themes related to the theme of critical expression were identified as self-criticism, respect for different opinions, evaluation and offering a suggestion. The sub-themes related to the theme of cultural expression were identified as value cultural heritage, understanding the artist, perceiving the work of art and have respect for the nature. The themes obtained within the scope of the findings of the study were determined as visual expression, critical expression and cultural expression. According to the results obtained from the study findings; as a result of the implementation of Visual Arts Course with outdoor education activities, positive reflections on the level of learning domains were determined. In this context, in the context of visual expression theme, meaningful results have been reached in terms of developing creative ideas, communicating skills, using an information in solving another issue, reaching results by reflecting and developing imaginative thinking skills. In the context of the theme of critical expression, meaningful results were reached in terms of self-criticism, respect for different opinions and offering solution-oriented suggestions. Finally, in the context of the theme of cultural expression, meaningful results were achieved in terms of gaining museum awareness, developing positive perception towards the Visual Arts Course and enhancing environmental awareness. In conclusion; It is known that the implementation of the Visual Arts Course with AHEE, provides interdisciplinary gains to the learner and there are possible limitations in the implementation process. In this context, the results of the use of AHEE were discussed in the literature. The study has shown that the idea of "being outside" creates a natural motivation for students. As a result; It is thought that this study which is enhanced through the implementation process can be a useful resource for teachers. This result is in accordant with the literature (Gilbertson vd. 2005, p. 129). As a result of the researcher's experience during the implementation process, it is seen that AHEE is an applicable model for every discipline. It is therefore hoped to give insight to art educators who wish to develop learning processes with AHEE. Within the framework of these results, it is proposed that the use of AHEE for Visual Arts Course be made widespread by supporting school programs and environmental factors (teacher, parents, natural area). 
GíRiş

Açık Havada Eğitim (AHE) tarih boyunca çok çeşitli şekillerde tanımlanmıştır. Reformcular tarafından sınıfların dışındaki ortamlarda aktif olma duygusunu ileten tireli şekilde yazılan out-door (dışarıda / açık alanda) ya da out-of-doors (açık havada) terimlerini kullanmıştır (Quay ve Seaman, 2013, s. 5). Donaldson ve Donaldson (1958, s. 17) tarafından öne sürülen önemli tanımlardan biri şu şekildedir: "Açık hava eğitimi dışarıda, dışarı hakkında ve dışarıya yönelik eğitimdir". Ford (1981) Açık Hava ve Çevre Eğitiminin ilkeleri ve uygulamaları ile ilgili kitabında Donaldson ve Donaldson'ın tanımında geçen dışarı hakkında ifadesinin AHE'nin konusunu sınırlandırdığı gerekçesiyle sorunlu bir ifade olduğunu iddia etmektedir. Ford açık havada pek çok konunun işlenebileceğini ve bu eğitim modeline dair anlayışın çevresel konularla sınırlı olmaması gerektiğini savunmaktadır. Ford'un (1986) bu tanımı aynı zamanda açık hava eğitiminin yeri, konusu ve amacı hakkında bilgi vermektedir. Bu bağlamda Ford, dışarıda ifadesi için AHE ile öğretilecek konuyla doğrudan temas etme durumuna ve katılımcılar arasında etkileşimin gelişeceğine vurgu yapmıştır. Dışarı hakkında, ifadesi için ise doğal çevre konusunda farkındalık düzeyinin ilk elden gelişmesini sağlayacağını savunmuştur. Bu küçük ancak anlamlı farklılığın önemli olduğu düşünülmektedir.

AHE'de katılımcılar yeme, içme ve barınma gibi temel ihtiyaçlarını doğal şartlarda gidermektedirler. Bu tür eğitimler genellikle yapılandırılmış bazı aktivitelerle gerçekleşmektedir. Eğitimde özel olarak tasarlanmış oyunlar ve yüksek element aktiviteleri gibi etkinlikler bulunmaktadır (Yazıcı, 2005, s. 57). Yaratıcı drama tarzı oyunlar bu tür eğitimlerde en yaygın kullanılan teknikler arasında sayılabilir. Oyunların genellikle deneysel ve davranışsal olarak tasarlanması önerilmektedir. AHE' de kişiler kendi konfor alanlarının dışına çıkarıldıklarında, aslında kendi rutin, alışageldikleri ortamın da dışına taşınmaktadırlar. Yani daha çok bilinmeyenle karşı karşıya kalmaktadırlar. Amaç, kişilerin bu alışımamış ortamlarda liderlik, karar verme ve uygulama becerilerini geliştirebilmektir. Kişilerin algı düzeyleri, kendi konfor alanlarının dışında arttığından kalıcı öğrenme ve sonucunda değişimin gerçekleşmesi de kolaylaşmaktadır. AHE'de katılımcılar bazen önceden belirlenmiş bir olgu karşısında bireysel çözüm üretmeye çalışırken bazen de rakip bir takıma karşı çözüm üretmeye çalışmaktadırlar. Oyunlarda çeşitli senaryolar yaratılarak, katılımcıların davranış kalıplarını ortaya çıkarıp bu davranış kalıplarını anlamaları sağlanmaktadır. Bunun doğal bir sonucu olarak da kişinin yeni bir davranış biçimi geliştirmesi beklenmektedir (Yazıcı, 2005, s. 58).

Ford (1986) birçok öğrenme tarzında olduğu gibi AHE'nin de yaşam boyu çaba gerektirebileceğini düşünmektedir. Bu bağlamda AHE'nin her yaştan, her beceriden, ve her sosyo-ekonomik kesimden insanın faydalanabileceği bir öğrenme yaklaşımı olduğu ifade edilmektedir. Priest için, AHE altı ana noktadan oluşmaktadır. Buna göre AHE: Bir öğrenme yöntemidir, deneyseldir. Açık havada gerçekleşir. Bütünseldir, dolayısıyla tüm duyuları kullanmayı gerektirir, disiplinler arası programlara dayanmaktadır, kuramsal çerçevesi insanları ve doğal kaynakları içeren ilişkiler hakkındadır (Priest, 1986, s. 13). Bu doğrultuda Priest AHE’yi; öğrenme için bir yer olarak; doğal çevre, bir konu olarak; ekolojik süreçler ve bir neden olarak kaynak yönetimi şeklinde tanımlanmıştır.) AHE çok sayıda konuyu ve çeşitli öğrenme stillerini kapsayabilmektedir. Örneğin AHEE'nde beyninin sağ tarafını kullanan öğrenciler çevresel farkındalık tekniklerinden faydalanırken, beyninin sol tarafını kullanan öğrenciler ise ekolojik ilkelerden faydalanabilirler. Oluşturulan bu iki farkındalık düzeyi aracılığıyla tüm çocuklar beynin her iki yarısına yönelik öğrenme stillerini kullanarak anlatılan konuyla ilgili bütüncül bir bakış açısı kazanabilirler (Ford, 1986).

Başka bir açıdan yaklaşan Gilbertson, Bates ve McLaughlin'e (2005, s. 6) göre; AHE, doğrudan ve çoklu-duyusal deneyimleri vurgulayan, açık alan çevresinde oluşan, doğa, toplum ve bireysel çevreleri kapsayarak bütünleşmiş öğrenme yaklaşımını kullanan bir öğretme ve öğrenme modelidir. Dolayısıyla açık havada yapılan eğitim programları, açık alanların kullanımı yoluyla bireyin fiziksel, duygusal, bilişsel, sosyal ve ruhsal düzeylerini yükseltmeye çalışmaktadır. Bu eğitim modelinde öğrencilere kendilerini zor durumlarla yüzleşerek karakterlerini oluşturmak için gerekli olan ortak gayeye adama konusunda ilham vermek ana amaçtır" (Robbins, 2015, s. 8). Bu bağlamda AHEE, birçok farklı disiplin için uygulanabilir öğrenme ve öğretme alternatifleri sunmaktadır. Sanat eğitimi de amaç ve uygulamaları bakımından AHEE ile benzerlik içeren bu disiplinlerden biridir. Varlığının temelini gerek nesneler arası, gerekse bireylerarası iletişime dayandıran ve kullandığı dil yönünden; bazen plastik, bazen ritmik, bazen fonetik olan sanat eğitimi için deneyimler kanalıyla öğrenmenin önemli olduğu düşünülmektedir.

Sanat eğitimi, duyusal etki faktörlerinin yaşantısal olarak içselleştirilmesi ile öğrencilerin ortaya koydukları potansiyel sayesinde, yeteneklerini açığa çıkartmakta da bir kanal görevi görmektedir. Eğitim hedefleri doğrultusunda işbirliği, dayanışma, yaratıcılığı geliştirme, problem çözme gibi davranışların geliştirilmesinde öğrenen, öğreten ve öğrenme ortamı arasındaki etkileşimin devamını sağlayacak en iyi çalışma alanlarından birisi doğadır. Doğada yaşanan deneyimlerde öğrenme gerçektir; fiziksel olarak etkin, bilişsel olarak anlamlı ve duyuşsal olarak, duyarlı ve güvenilir olmayı teşvik eder (Priest ve Gass, 1997; Coşkun, 2005: Akt. Özen, 2010, s. 28). Ana söyleminde yaratıcılık olgusu olan sanat eğitimine sürdürülebilirlik açısından bakıldığında, zaman ve mekan bağlamındaki sınırların öğrencilerin hareket alanını kısıtladığı söylenebilir. Dolasıyla sanat eğitimi için sınırları çizilmiş ortam ve sınırlandırılmış içerikle sınırsız hayallerin kurulmasına dair beklentilerin karşılanması güçleşmektedir. Bu doğrultuda sınıfın dışında, doğal ortamlarda gerçekleşen AHEE'nin sanat eğitimi için farklı bir alternatif oluşturabileceği düşünülmektedir. AHEE ile yapılandırılmış bir görsel sanatlar dersinde; takım çalışmaları ile akran ilişkileri gelişimi ve çevresel farkındalık gibi özellikleri geliştirmeye teşvik edebileceği öngörülmektedir. Adkins ve Simmons'e göre (2002, s. 3) AHE yaklaşımı rastlantısal deneyimlere ve açık deneyimler yoluyla sağlanan öğrenme süreci içermektedir. Bu noktadan hareketle AHEE'nin Görsel Sanatlar Dersi için sunacağı rastlantısal deneyimlerin sanat eğitimi öğrenme alanlarına yansımalarının paylaşılarak etraflıca tartışılmasının alana faydalı olacağı düşünülmektedir. 


\section{Problem Durumu}

Görsel sanatlar dersinde AHEE’nin kullanılmasının bir araştırma problemi olarak ele alınması, dersin öğretim programının da hedeflerine dayanmaktadır. Bu sav üzerinden; Görsel Sanatlar Öğretim Programı’nda (GSÖP) geçen “Eğitim ortamları sınıf içi ve sınıf dışı (park, bahçe, sergi tarihi yapılar, sanatçı atölyeleri, sanat ve kültür merkezleri vb.) olarak zenginleştirilmelidir" (Milli Eğitim Bakanlığı [MEB], 2007, s. 5) ifadesi esas alınmıştır. GSDÖP’nda belirlenen program özelliklerinden olan bu ifade eğitimciler ve öğrenciler tarafından daha çok boş zaman doldurma, gezi gözlem zamanı olarak algılanmaktadır. Fakat program detaylı incelendiğinde, sınıf dışında tanımlanan zamanla, sınıf içinde olduğu gibi derse ve ders kazanımlarına entegre bir süreç ifade edildiği görülmektedir. Bu doğrultuda; AHEE ile yapılandırılan dersin, ders planına bağlı kalınarak açık havada işlenmesinin, Görsel Sanatlar Dersi öğrenme alanlarına nasıl yansıdığı bu araştırmanın temel problemidir.

\section{Amaç}

Araştırmada, AHEE ile gerçekleştirilen Görsel Sanatlar dersinin uygulama sonuçlarının ortaya konulması amaçlanmıştır. Araştırmanın amacı doğrultusunda; araştırmacı tarafından AHEE ile yapılandırılan Görsel Sanatlar derslerindeki temel öğrenme alanları olan; Görsel İletişim, Görsel Eleştiri ve Kültürel Bilinç bağlamında gözlemlenmesi ise çalışmanın alt amaçlarını oluşturmaktadır.

\section{YÖNTEM}

Araştırma desenine karar verme aşaması aynı zamanda karar verilen desene yönelik çalışma çerçevesini planlama sürecidir. Akar’a (2016, s. 121) göre nitel çalışma yapmak için araştırmacı kendi donanımını dikkate alarak ve görgül çalışmaların gereği olarak çalışmanın amacını, araştırma alt sorularını, alanyazın ve durumu; bir başka ifadeyle örnek olayın neden seçildiğine ait gerekçesini açıkça ortaya koyarak başlamalıdır. Çalışmanın bu bölümünde araştırmada kullanılan yönteme ilişkin ayrıntılara yer verilmiştir.

Bu araştırmada, durum çalışması deseninden faydalanılmıştır. Sınırlı bir sistemin derinlemesine betimlenmesi ve incelenmesidir" ifadesiyle açıklamaktadır. Bu bağlamda araştırma süreci açısından durum çalışması, güncel bir olgu ile bağlam arasındaki sınırlar tam olarak belirgin değilse olguyu gerçek hayattaki bağlamıyla inceleyen ampirik bir araştırmadır (Merriam, 2013, s. 40). Durum çalışması katılımcı gözlemleri, derinlemesine görüşmeler ile doküman toplama yoluyla elde edilen ve analiz edilen verilerin derinlemesine ve boylamsal olarak incelenmesini içerir (Glesne, 2013, s. 13). Dolayısıyla durum çalışmasında, veriler arası anlam ve ilişkilerin açıklamasına yönelik planlı bir süreç ifade edilmektedir. "Araştırma deseniyle ilgili kararlar veri toplama sürecinde ortaya çıkan bulgulara göre yeniden dikkate alınabilir. Bu yaklaşımda veriler toplandıkça analiz edilir" (Akar, 2016, s. 121). Bu bağlamda araştırma başlamadan önce kullanılacak desene ilişkin ön çalışmalar araştırma süresince devam etmiştir. Araştırmada ardışık durum çalışması modeli benimsenmiştir. Ardışık durum çalışması modeli, Akar'ın (2016, s. 121) Yin' den (2014) aktardığı biçimi ile Şekil 1'de verilmiştir.

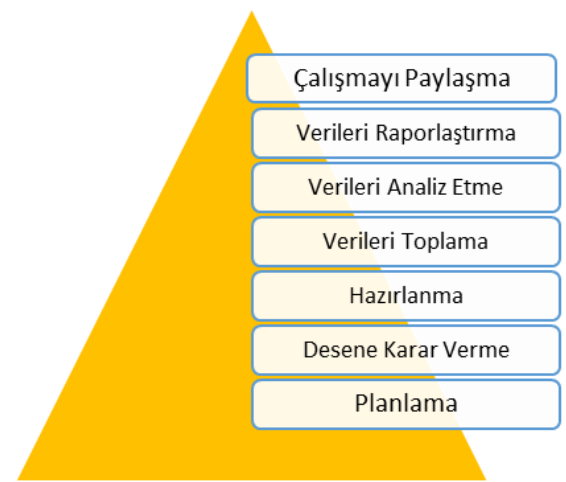

Şekil 1. Yin'in Ardışık Durum Modeli (Akar, 2016, S. 121)

Nitel araştırmalarda, doğası gereği her zaman karar verilen desene ilişkin sabit bir yol izlenmesi söz konusu olmayabilir. Bu bağlamda durum çalışmasına başlamak için dikkat edilmesi gereken iki husus vardır. Bunlar, bir araştırma yaklaşımı olarak neden durum çalışmasının seçildiği ve sürece ne zaman başlanacağıdır (Yin, 2014: Akt. Akar, 2016, s. 121). Bu sorular aynı zamanda ardışık durum çalışması modelinin planlama adımıyla başlayan sürecini işaret etmektedir (Bknz. Şekil 1). Çalışılan modelin tanımlandığı bu bölümde ilk olarak, “Bir Araştırma Yaklaşımı Olarak Neden Durum Çalışması Seçildi?” sorusu cevaplanmaya çalışılmıştır.

\section{Bir Araştırma Yaklaşımı Olarak Neden Durum Çalışması Seçildi?}

Bu araştırmada durum çalışması deseninin seçilmesinin temel nedeni, seçilen konunun güncel bir konu olması ve araştırmacının konuyu derinlemesine inceleme gereksinimi duyulmasıdır. Diğer bir bakış açısıyla Akar'ın (2016, s. 113) belirttiği üzere: “Durum çalışması bir güncel olayı derinlemesine ve bütünsel olarak gerçekçi dünya perspektifinden incelemeyi gerektirir " savından yola çıkılmıştır. Bu bağlamda durum çalışması deseninin seçilmesinin nedeni araştırmanın amacı olan "AHEE ile yapılandırılmış Görsel Sanatlar Dersi'nin, öğrenme alanlarına yönelik gözlemlerin ortaya konulması" cümlesi üzerinden açıklamak yerinde olacaktır. Buna göre; 
1. Araştırmada, Görsel Sanatlar Dersi için AHE gibi güncel ve yeni bir eğitim modeli kullanılması, bu araştırmanın bir durum çalışması deseni olarak çalışılmasının nedenlerinden biridir. Literatürde henüz çok yeni olan AHE, yurt dışındaki eğitim programında, formal/informal olarak yaygın kullanımına karşın Türkiye'de yeni ivme kazanma yolundadır. Dolayısıyla araştırma konusunun Görsel Sanatlar Dersi için yeni bağlamlar oluşturmak adına araştırma ve geliştirmeye uygun bir konu olduğu düşünülmektedir.

2. Görsel Sanatlar Dersi'nin gerçekleşme süreci açısından bakıldığında ise bu çalışmada kullanılan programın, alışımışın dışında bir ortamda (okul binası dışında) tasarlanmış uygulamalara dayalı olarak gerçekleşmesi durumu ortaya çıkmaktadır. Araştırmanın verilerine dayalı örüntüyle birlikte ayrıntılı betimlemeler ve analizlere duyulan gereksinim araştırmada durum çalışması deseni kullanılmasının nedenlerindendir. Bununla birlikte Merriam’a (2013, s. 14) göre bir olgunun durum çalışması olarak çalışılabilmesi için belirli bir program ya da belirli bir öğrenci sınıfı ele alınmalıdır. Bu çalışmada da durumun somut bir model uygulaması olması nedeniyle, uygulanan modelin öğrenme alanı üzerindeki yansımalarına ilişkin gözlem süreci bir durum olarak ele alınmıştır.

3. Araştırma, Görsel Sanatlar Dersi'nin AHEE ile gerçekleşmesi durumunun öğrenme alanlarına yansımasının gözlendiği bir uygulama örneği olarak nitelendirilmiştir. Bu şekilde nitelendirilen programın derinlemesine tasviri ve analizi sayesinde benzer araştırmacılar için kapsamlı bir örnek teşkil edeceği düşülmektedir.

Durum çalışması deseninin kendi içindeki türlerine bağlamında bakıldığında ise bu araştırma, bütüncül tek durum desenine dayandırılmıştır. Tek durum deseninde isminden anlaşılacağı gibi tek bir analiz birimi (bir birey, kurum, program ya da okul) vardır (Yıldırım ve Şimşek, 2011, s. 290). Bu araştırma, tek bir okulda uygulanmıştır. Akar'ın (2016, s. 126) durum belirleme süreci şemasına göre; araştırmada makro düzeyde tasvir için AHE'ye ilişkin kavramsal çerçeve, mikro düzeyde tasvir için ise araştırmacı tarafından hazırlanan uygulama programının öğrenme alanı üzerindeki yansımaları ele alınmıştır.

\section{Araştırmanın Kapsamı}

Bu araştırma, ortaokul beşinci sınıfta okuyan sekizi odak olmak üzere toplam 21 öğrenci ve ders öğretmeninin katılımının yanı sıra bir araştırmacı ve üç dış gözlemci (alan dışı), iki iç gözlemci (alan içi) ve iki görsel kayıt görevlisi ile gerçekleştirilmiştir. Araştırmayı oluşturan 21 öğrenciden sekizi odak öğrenci olarak belirlenmiştir. Odak öğrencilerin seçiminde gönüllülük esas alınmıştır. Araştırmada kullanılan tüm veri setinde öğrenciler için kullanılan isimler etik ilkeler gereğince gerçek dışıdır. Katılımcı isimleri bağlamına uygun olarak faklı bir isimle aktarılmıştır. Beşi erkek, üçü kız olmak üzere toplam sekiz odak öğrencinin yaş ortalaması 11'dir. Gerek araştırmaya katılım, gerekse de odak öğrenci olma durumuna ilişkin veli izin formları araştırma öncesinde öğrenci velilerine gönderilmiştir. Veliler tarafından onaylanan formlar ıslak imzalı olarak toplanmıştır.

\section{Araştırma Uygulamalarının Hazırlık Aşaması}

Araştırma sürecine yönelik ilk aşama, araştırma uygulamalarına ilişkin konu seçiminin nasıl yapılacağı kısmıdır. Bu doğrultuda araştırmanın yapıldığı okulda bulunan görsel sanatlar öğretmeninden 5. sınıf Görsel Sanatlar Dersi yıllık planları ve ders zümre toplantı çıktıları alınarak ayrıntılı olarak incelenmiştir. Incelenen yıllık planlara dayalı olarak uygulama programı oluşturulmuştur. Buna göre Görsel Sanatlar Dersinin üç temel öğrenme alanı olan Görsel İletişim ve Biçimlendirme, Görsel Sanatlar Kültürü ve Müze Bilinci üzerine odaklanılmıştır. Yılık planlarda bulunan kazanımlar dikkate alınarak: altı hafta süresince uygulamalara kaynak olan görsel sanatlar dersi konularıyla eşleştirilmiştir. Böylece günlük planlar oluşturulmuştur.

Tablo 1. Görsel Sanatlar Dersi yıllık planında bulunan konuların AHE etkinlikleriyle eşleştirmeleri

\begin{tabular}{lll}
\hline Öğrenme Alanı & M.E. B. Müfredat Dersleri & AHE Etkinlikleri \\
\hline $\begin{array}{l}\text { Görsel iletişim ve } \\
\text { biçimlendirme }\end{array}$ & Renk çemberi yapıyorum & Renkli beneklerle oyun \\
& Nokta ile çizginin dansı & Asimetrik izler \\
Görsel Sanatlar Kültürü & $\begin{array}{l}\text { Yöresel meslekler } \\
\text { Bir cümle bir hikâye }\end{array}$ & Farklı olanı bul \\
& Türkiye'nin önemli mekânları & Haydi, faklı anlatalım \\
Müze Bilinci & Ülkemizin güzellikleri & Mürel tarama \\
\hline
\end{tabular}

Tablo 1.'de Günlük planlar için 5. sınıf Görsel Sanatlar Dersi yıllık planında bulunan konuların, kazanım ve amaç cümlelerine göre AHE etkinlikleriyle eşleştirmeleri yapılmıştır. Bu eşleştirmeye göre M.E. B. Müfredat Dersleri içerikleri alınarak AHE etkinliğine dayalı uygulamalar çerçevesinde günlük planlar oluşturulmuştur. 


\begin{tabular}{ll}
\hline 1.DERS & \\
\hline Ders & Görsel Sanatlar \\
Sınıf & 5/C \\
Yaklaşık Süre & 1 Ders saati \\
Temel Beceriler & Ana ve ara renkleri ayırt etme. \\
Öğrenme Alanı & Görsel Sanatlarda Biçimlendirme. \\
Kazanım & 1. Renk ilişkilerini kavrar. Ana renklerle oluşan ara renkleri kavrar. (Görsel Sanatlar Bilinci/ GSB.) \\
Araç Ve Gereçler & Plastik eldiven, akrilik boya (ana ve ara renkler), plastik tabak, kumaş (ara renkler ve beyaz), şeffaf \\
& muşamba, elişi kağıdı (ana ve ara renklerde), düdük, tişört, etkinlik şapkası. \\
Teknikler & Akrilik boya, elleri kullanma \\
Yöntemler & AHEE, anlatım, oyun oynama, uygulamalı çalışma. \\
Duyuşsal Ve Düşünsel Hazırlık & Öğrencilerden renklerin oluşumunu kendi ellerini kullanarak görürler. Renklerin oluşturmaları \\
& beklentisi bir oyun düzeni içinde verildiğinden dolayı aynı zamanda bir oyun süreci içinde akran \\
& ilişkileri oyun kuralları vb. eylemleri de gerçekleştirerek çok yönlü düşünmeleri sağlanır.
\end{tabular}

\section{SÜREÇ}

1. Öğrenciler, öğretmenin renkleri göstererek birleşimlerindeki rengi sorması ile birlikte önlerine gelen kartonlardan ana ve ara renkleri bulurlar. Daha sonra ana renklerin birleşimiyle oluşan ara rengi bulup sıralamasını yaparlar (5 dakika).

2. Öğrenciler gruplara ayırılır. Grup başına bir tane olmak üzere kumaşlarla hazırlanmış düzenekler gösterilir. Öğrencilerden eldivenlerinizi giymeleri ve grupça toplanıp kimin sözcü olacağına karar vermeleri istenir. Toplanan gruplar büyük muşambaların serili olduğu yerde tek sıra halinde düdük sesiyle etkinliğin başlaması beklenir (10 dakika).

3. Yerde hazırlanmış düzenekte naylon muşamba üzerine yapıştırılmış beyaz ve ara renkte (turuncu, mor, yeşil) olmak üzere dört renk kumaş ve her muşambada plastik kaplar içinde üç ana renkte (kırmızı, sarı, mavi) boya bulunur. Her kumaş üzerine çizilmiş üç tane yuvarlak şekil ve muşamba da her biri bir kumaşa denk gelecek şekilde 1'den 4'e kadar rakamlar yazılır. Öğrencilere; 1'den 4'e kadar bir rakam söylenir. Bu rakam hangi renge denk geliyorsa sıradaki öğrenci söylenen rakamın rengini oluşturan renkleri bulması istenir. Öğrencilerden kumaşların önünde bulunan ilgili boya kaplarına ellerini batırarak (her el bir renk olacak) önce bir eli sonra diğer rengi söylenen kumaş üzerindeki daireye basarak işlemi tamamlamaları istenir (20 dakika).

4. Gruplara tek tek söz verilerek, grup sözcüsünün diğer arkadaşlarına kumaşlardaki renkleri açıklaması istenir. Grupça yapılan etkinliğin kısaca anlatması sağlanır. Diğer öğrencilerden de dönüt alınır. Her gruba doğru yaptıkları renk oranında 1'den 5'e kadar bir değerlenme puanı verilir. Bu bütün gruplar için tekrar edilerek ana ve ara renklerin kavratılması ile ilgili etkinlik tamamlanır (5 dakika).

\section{DEĞERLENDIRME}

1. Her öğrencinin sürece katılıp katılmadığı değerlendirilir.

2. Öğrencilere yaptıkları çalışmalara ilişkin sorular yöneltilir:
a) Ana ve ara renklerinin nelerden oluştuğunu kavrayabildiniz mi?
b) Uygulama esnasında en çok hoşunuza giden şey ne oldu?
c) Uygulama esnasında zorlandınız mı?
d) Bu uygulamayı oyun oynayarak gerçekleştirmek hoşunuza gitti mi?

Tablo.2' de “Renkli Beneklerle Oyun” etkinliği için AHE ile oluşturulmuş ders planında temel beceriler, öğrenme alanı, kazanım, araç ve gereçler teknikler yöntemler duyuşsal ve düşünsel hazırlık detayları ile birlikte dersin AHE formatında işlenme süreci ve ders sonu değerlendirme esaslarına yer verilmiştir. Buna göre M.E. B. Müfredatındaki "Renk çemberi yapıyorum" adlı dersin kazanım ve öğrenme alanları açısından benzerlikler dikkate alınarak; "Renkli Beneklerle Oyun" etkinliği için AHE ile oluşturulmuş ders planı tasarlamıştır.

Tablo 3. Asimetrik izler etkinliği için AHE ile oluşturulmuş ders planı

\begin{tabular}{ll}
\hline 2.DERS & \\
\hline Ders & Görsel Sanatlar \\
Sınıf & 5/C \\
Yaklaşık Süre & Ders saati \\
Temel Beceriler & Görsel sanatlar çalışmasını oluştururken uygulama basamaklarını kullanır. \\
Öğrenme Alanı & Görsel Sanatlarda Biçimlendirme \\
Kazanım & 1. Nokta ve çizgi etkisini üç boyutlu çalışmalarında kullanır.(G.S. B.) \\
& 2. Görsel sanatlar çalışmalarını oluştururken sanat elemanlarını ve tasarım ilkelerini kullanılır.(G.S. B.) \\
Araç Ve Gereçler & Kumaş (siyah 6 metre) tebeşir, çekiç, tişört, doğadan malzemeler (yaprak ,toprak, taş, dal vs.) düdük, \\
& etkinlik şapkası. \\
Teknikler & Form oluşturma çalışması, üç boyutlu çalışma. \\
Yöntemler & Oyun oynama, anlatım, uygulamalı çalışma \\
Duyuşsal Ve Düşünsel Hazırlık & Öğrencilerden; çizgi simetri ve asimetri konusundaki bilgileri sorulur. Bedenlerinin kullanarak simetri \\
& ve asimetrik duruşu hissetmeleri sağlanır. \\
\hline
\end{tabular}


SÜREÇ

1- Öğrencilere farklı türde yapraklar rastgele dağıtılır. Daha sonra 2'şerli grup olmaları istenir. Her gruba 1'er tane çekiç verelim. Ve çocukları bahçede buldukları herhangi bir zeminde konumlandırılır (5 dakika).

2- Öğrencilerin tişörtlerine yapılan çekiçle yaprak baskı örneği bütün çocukların görebileceği şekilde gösterilir. Her öğrenciden kendi tişörtüne bu baskıyı yapmaları istenilir (5 dakika).

3- Baskı yapılan tişörtlerin desenine göre benzer desenler gruplandırılır. Simetri asimetri kavramları ile ilgili oyun kuralları anlatılır $(5$ dakika).

4- Öğrencilerle birlikte simetri asimetri oyunu oynatılır. Son öğrencinin kazanan grubu kazandırdığı ifade edilerek kazanan gruba işaret kurdelesi takılır. Oyun sonlandırılır(15 dakika).

5- Öğrencilerden tekrar çember olmaları istenir. Bugünkü etkinler üzerine konuşularak dönütler verilir. Öğrencilere teşekkür edilerek etkinlik de tamamlanır (5 dakika).

\section{DEĞERLENDIRME}

1.Her öğrencinin sürece katılıp katılmadığı öğrenci kontrol listesi ile değerlendirilir.

2. Öğrencilere yaptıkları etkinliğe ilişkin sorular yöneltilir:
a) Bu çalışmayı yaparken nelere dikkat ettiniz?
b) Uygulama esnasında en çok hoşunuza giden şey ne oldu?
c) Uygulama esnasında zorlandığınız bir konu oldu mu?

Tablo.3' de "Asimetrik İzler" etkinliği için AHE ile oluşturulmuş ders planında temel beceriler, öğrenme alanı, kazanım, araç ve gereçler teknikler yöntemler duyuşsal ve düşünsel hazırlık detayları ile birlikte dersin AHE formatında işlenme süreci ve ders sonu değerlendirme esaslarına yer verilmiştir. Buna göre M.E. B. Müfredatındaki “Nokta ile Çizginin Dansı” adlı dersin kazanım ve öğrenme alanları açısından benzerlikler dikkate alınarak; "Asimetrik İzler" etkinliği için AHE ile oluşturulmuş ders planı tasarlamıştır.

Tablo 4. Farklı olanı bul etkinliği için AHE ile oluşturulmuş ders planı

\section{DERS}

Ders
Sınıf
Yaklaşık Süre
Temel Beceriler
Öğrenme Alanı
Kazanım
Araç ve Gereçler
Teknikler
Yöntemler
Duyuşsal Ve Düşünsel Hazırlık

\section{Görsel Sanatlar}

$5 / C$

1 Ders saati

Eleştirel düşünme, yaratıcı düşünme, kendini ifade etme, estetik algının geliştirilmesi, sanat aracılığıyla iletişim kurma, görsel okuma.

Görsel sanatlar kültürü, Müze Bilinci.

1. Farklı kültürlerin sanatı ve sanatçıları arasında benzerlik ve farkları açıklar (M.B.)

2. Geçmişte ve günümüzde yapılmış olan sanat eserleri arasındaki farkları belirler (M.B.)

3. Sanat objesini meydana geldiği hammaddeyi tanır (G.S.B.).

Her biri farklı ham maddeden meydana gelen farklı objeler (kireç, toprak, metal), tebeşir, kumaş (üç farklı renkte), düdük, etkinlik şapkası.

Gözlem yapma, izleme.

Gösterim, araştırma, soru-cevap, uygulamalı çalışma.

Öğrencilerden gruplarına verilen her bir malzemeyi yapı, form ve hammadde açısından incelemeleri istenir. Grup olarak ortak hareket etmeleri beklenir. Alışılmışın dışında bir farklılığı olduğuna karar verdikleri nesneyi belirledikten sonra gerekçesi konusunda ortak fikir yürütmeleri istenir.

SÜREÇ

1- Öğrencilerden çevrelerinde duydukları sesleri hatırlamaları istenir. Akıllarına gelen sesleri sırayla çıkarmaları söylenir (5 dakika).

2- Öğrencilerden bulundukları sokağa dair bir görüntü hayal etmeleri istenir. Sonra topluca bu hayalleri birleştirip bedenlerini kullanarak büyük sokak i fotoğrafı oluşturmaları istenir (5 dakika).

3- Her öğrenciyi teker teker alarak elleriyle oluşturdukları kadraj cetvelini kullanarak arkadaşlarından kadrajlar almaları istenir (5 dakika).

4- Öğrenciler 3 büyük gruba ayırılır. Her bir gruba üç ana renkten biri olan, üzeri tebeşirle 4'e bölünmüş bir kumaş dağıtılır. Dağıtılan yapışkan kurdeleleri tişörtlerine yapıştırmaları istenir. Her gruba 4'er tane obje verilir. Bu objeleri inceleme çerçevesine göre detaylı olarak incelemeleri istenir (10 dakika).

5- Öğrencilerden kendilerine göre farklı olan objeyi belirlemeleri istenir. Öğrencilerin Beyin fırtınası, eleştiri ve tartışma süreçlerini yaşamaları için teşvik edilir. Gruplar birbirlerinin gruplarını gezerek farklııkları neden sonuç ilişkisiyle sorgulamaları sağlanır (10 dakika).

6- Toplam Süre dolduktan sonra tüm sınıfı toplanarak çember şekli olunur. Her gruptan bir öğrenci çemberin ortasına alınır ve grupça seçtikleri objeyi göstererek neden seçtiklerini tüm arkadaşlarıyla paylaşır (5 dakika). 


\section{DEĞERLENDIRME}

1.Her öğrencinin sürece katılıp katılmadığı öğrenci kontrol listesi ile değerlendirilir.

2. Öğrencilere yaptıkları etkinliğe ilişkin sorular yöneltilir:
a) Bu çalışmayı yaparken nelere dikkat ettiniz?
b) Uygulama esnasında en çok hoşunuza giden şey ne oldu?
c) Uygulama esnasında zorlandığınız bir konu oldu mu?

Tablo.4' de "Farklı Olanı Bul” etkinliği için AHE ile oluşturulmuş ders planında temel beceriler, öğrenme alanı, kazanım, araç ve gereçler teknikler yöntemler duyuşsal ve düşünsel hazırlık detayları ile birlikte dersin AHE formatında işlenme süreci ve ders sonu değerlendirme esaslarına yer verilmiştir. Buna göre M.E. B. Müfredatındaki "Yöresel Meslekler" adlı dersin kazanım ve öğrenme alanları açısından benzerlikler dikkate alınarak; "Farklı Olanı Bul” etkinliği için AHE ile oluşturulmuş ders planı tasarlamıştır.

Tablo 5. Haydi farklı anlatalım etkinliği için AHE ile oluşturulmuş ders planı

\begin{tabular}{ll}
\hline $4 . D E R S$ & Görsel Sanatlar \\
\hline Ders & $5 / C$ \\
Sınıf & 1 Ders saati \\
Yaklaşık Süre & Yaratıcı düşünme, araştırma, girişimcilik, Türkçe' yi doğru, güzel ve etkili kullanma, kendini ifade \\
Temel Beceriler & etme, görsel okuma, başladığı işi bitirme. \\
& Görsel Sanat Kültürü, Görsel Sanatlarda Biçimlendirme \\
Öğrenme Alanı & 1. Doğa ve inşa edilmiş çevreyi karşıllaştırır. \\
Kazanım & 2. Hayal gücünü kullanılır. \\
& 3.Gözlem yetesi gelişir. \\
& 4. Kendini doğru ifade etme becerisi kazanır. \\
& 5. Grup olarak çalışır. Akran ilişkileri gelişir. \\
& Kağıt, kalem, ses kaydı cihazı, esnek ip, düdük, etkinlik şapkası. \\
Araç ve Gereçler & Yazma, okuma \\
Teknikler & Soru-cevap, anlatım, araştırma, işbirlikli çalışma. \\
Yöntemler & Öğrencilerden; ormandaki ağaçları çok detaylı incelemeleri istenir. sonra gerekçesi konusunda \\
Duyuşsal ve Düşünsel Hazırlık & ortak fikir yürütmeleri istenir.
\end{tabular}

SÜREÇ

1- Öğrencilerin ellerinde herhangi bir bilgi olmaksınız kazı çalışması konulu derste çalıştıkları ilgili ağacı bulmaları beklenir (5 dakika).

2- Öğrenciler grupça buldukları ağacın etrafında daire halinde konumlandırııır (5 dakika)

3- Bu konu için yapacak etkinliklere ilişkin detaylar verilir (5 dakika).

4- Her gruptan onlara verilen halatın içerisine girerek halatla birlikte halka oluşturmaları istenir ( 5 dakika).

5- "Yakınlaş" "uzaklaş" diye yönergeler verilerek öğrencilerin ağacı tüm detaylarıyla incelemeleri sağlanır (5 dakika).

6- Her gruba birer tane defter ve kalem verilir. Öğrencilerden grupça incelemiş oldukları ağacı anlatan bir metin oluşturmaları istenir (15 dakika).

\section{DEĞERLENDIRME}

1.Her öğrencinin sürece katılıp katılmadığı öğrenci kontrol listesi ile değerlendirilir.

2. Öğrencilere yaptıkları etkinliğe ilişkin sorular yöneltilir:
a) Bu çalışmayı yaparken nelere dikkat ettiniz?
b) Uygulama esnasında en çok hoşunuza giden şey ne oldu?
c) Uygulama esnasında zorlandığınız bir konu oldu mu?

Tablo.5' de "Haydi Farklı Anlatalım” etkinliği için AHE ile oluşturulmuş ders planında temel beceriler, öğrenme alanı, kazanım, araç ve gereçler teknikler yöntemler duyuşsal ve düşünsel hazırlık detayları ile birlikte dersin AHE formatında işlenme süreci ve ders sonu değerlendirme esaslarına yer verilmiştir. Buna göre M.E. B. Müfredatındaki "Bir cümle bir hikâye" adlı dersin kazanım ve öğrenme alanları açısından benzerlikler dikkate alınarak; "Haydi Farklı Anlatalım” etkinliği için AHE ile oluşturulmuş ders planı tasarlamıştır. 
Tablo 6. Görsel tarama etkinliği için AHE ile oluşturulmuş ders planı

\begin{tabular}{|c|c|}
\hline 5.DERS & \\
\hline Ders & Görsel Sanatlar \\
\hline Sinıf & $5 / C$ \\
\hline Yaklaşık Süre & 1 Ders saati \\
\hline Temel Beceriler & $\begin{array}{l}\text { Araştırma, çevre ve doğa bilinci kazanma, estetik yaşam kültürü edinme, sorumluluk alma, } \\
\text { başladığı işi bitirme. }\end{array}$ \\
\hline Öğrenme Alanı & Müze Bilinci \\
\hline Kazanım & 1. Sanatçıların, mekânı belirtmek için ışık ve gölgeyi nasıl kullandığını tartışır. (G.S.B.) \\
\hline & 2. Kompozisyonlarında üç boyutluluk etkisi yaratmada ışık ve gölgeyi kullanır. \\
\hline & 3. Geçmişten günümüze yapılmış olan kültürel ve tarihi miras hakkında bilgi edinir (M.B.) \\
\hline Araç Ve Gereçler & $\begin{array}{l}\text { Siyah kumaş ( } 6 \text { metre) , beyaz tebeşir, Türkiye haritası, açık hava ve ören yeri görselleri, plastik top, } \\
\text { doğadan malzemeler (taş, yaprak, plastik ve kutu atıkları, dal vs.) düdük, etkinlik şapkası }\end{array}$ \\
\hline Teknikler & Çizgi, üç boyutlu düzenleme yapma \\
\hline Yöntemler & Gösterim, soru-cevap, beyin fırtınası uygulamalı çalışma. \\
\hline Duyuşsal Ve Düşünsel Hazırlık & $\begin{array}{l}\text { Öğrencilerimizden; Türkiye haritasında işaretlenmiş olan tarihi mekanlar ve ören yerleri hakkında } \\
\text { grupça fikir yürütmeleri istenir. Öğrencilerden, okul bahçesi ve yakın çevreden topladıkları doğal } \\
\text { (bitki, ağaç kabuğu, ot, sap vb.) ve yapay (naylon parçaları, karton kutular, şişeler vb.) materyaller } \\
\text { ile seçtikleri tarihi mekanı kompoze etmeleri istenir. Öğrencilerden grup olarak kompozisyonlarını } \\
\text { canlandırmaları için prova yapmaları istenir. }\end{array}$ \\
\hline
\end{tabular}

SÜREÇ

1- Öğrencilerle zihinsel işlem hızlarını el, göz ve beyin koordinasyonunu yoklamayı amaçlayan "Top ile sayı tamamlama" oyunu oynanır. (5 dakika).

2- Öğrenciler yere serili olan kumaş üzerindeki Türkiye haritası etrafına toplanır. Renkli sakızlar aracılığıyla öğrenciler gruplanır. Her grup bir bölgeye yerleştirilir. (5 dakika)

3- Türkiye kültürel zenginlikleri haritasını gruplara dağıtılır. Her gruptan bulundukları bölgeye yönelik bir yapıt, yer ya da ürün seçmelerini istenir. Her grup seçimini yapar. (5 dakika)

4- Öğrencilerden her bölgede seçilen yerle ilgili bir kompozisyon yapmaları istenir. Bu kompozisyon için çevreden malzeme toplamaları için yönerge verilir. Her grubun kompozisyonu için dönüt verilir. (5 dakika)

5- Öğrencilerden kompoze ettikleri yeri canlandırmaları için yönerge verilir. Her grup diğer gurubun canlandırmasını izler. Gruplar topluca kompozisyon için topladıkları malzemeler aracığıyla ritim etkinliği yaparlar. (15 dakika)

6- Öğrencilerden tekrar çember olmaları istenir. Bugünkü etkinler üzerine konuşularak dönütler verilir. Öğrencilere teşekkür edilerek etkinlik de tamamlanır. (5 dakika)

\section{DEĞERLENDIRME}

1.Her öğrencinin sürece katılıp katılmadığı öğrenci kontrol listesi ile değerlendirilir.

2. Öğrencilere yaptıkları etkinliğe ilişkin sorular yöneltilir:

a) Bu çalışmayı yaparken nelere dikkat ettiniz?

b) Uygulama esnasında en çok hoşunuza giden şey ne oldu?

c) Uygulama esnasında zorlandığınız bir konu oldu mu?

Tablo.6' da “Görsel Tarama” etkinliği için AHE ile oluşturulmuş ders planında temel beceriler, öğrenme alanı, kazanım, araç ve gereçler teknikler yöntemler duyuşsal ve düşünsel hazırlık detayları ile birlikte dersin AHE formatında işlenme süreci ve ders sonu değerlendirme esaslarına yer verilmiştir. Buna göre M.E. B. Müfredatındaki "Türkiye’nin önemli mekânları" adlı dersin kazanım ve öğrenme alanları açısından benzerlikler dikkate alınarak; "Görsel Tarama" etkinliği için AHE ile oluşturulmuş ders planı tasarlamıştır.

Tablo 7. Müzemi oluşturuyorum etkinliği için AHE ile oluşturulmuş ders planı

\begin{tabular}{ll}
\hline $6 . D E R S$ & \\
\hline Ders & Görsel Sanatlar \\
Sınıf & 5/C \\
Yaklaşık Süre & Ders saati \\
Temel Beceriler & Kendini ifade etme, araştırma, çevre ve doğa bilinci kazanma, estetik yaşam kültürü edinme, \\
& sorumluluk alma, empati duygusunu geliştirme, başladığı işi bitirme. \\
Öğrenme Alanı & Görsel Sanatlarda Biçimlendirme, Müze Bilinci. \\
Kazanım & 1. Farklı kültürlerin sanatı ve sanatçıları arasında benzerlik ve farkları açıklar (M.B.) \\
& 2. Geçmişte ve günümüzde yapılmış olan sanat eserleri arasındaki farkları belirler (M.B.) \\
& 3. Sanat objesini meydana geldiği hammaddeyi tanır (G.S.B.). \\
Araç ve Gereçler & Diş fırçası, geniş fırça, çekiç, pet şişe su, modelaj kalemleri, bez, beyaz kumaş, çöp şiş, çekiç, tahta \\
Teknikler & kaşık, düdük, etkinlik şapkası \\
Yöntemler & Kazı yapma \\
Duyuşsal Ve Düşünsel Hazırlık & Soru-cevap, gezi-gözlem, araştırma, gösterip yaptırma, uygulamalı çalışma. \\
\hline
\end{tabular}


SÜREÇ

geçen bütün aşamalar hakkında fikir sunmaları beklenir. Çalışılan ortamın orman olması sebebiyle gözlerinin kapatarak orman seslerine kulak vermeleri istedir. Bu deneyimin ardından öğrencilerden hislerini birer kelimeyle arkadaşlarıyla paylaşmaları istenir.

1- Öğrencilerden gözlerini kapatıp bir dakika boyunca ormanı dinlemeleri istenir ( 5 dakika)

2- Öğrencileri ortama ısındırma çalışması yapılır. Ormanlar ve AHEM uygulamaları arasındaki ilişkiyi öğrencilere anlatılır (5 dakika).

3- Bu ders için yapacak etkinliklere ilişkin detaylar verilir (5 dakika).

4- Öğrenciler rastgele seçecekleri kurdele renklerine göre toplam 3 grup olacak şekilde gruplandırılır. Daha önceden hazırlanan alan haritaları her gruba birer tane olacak şekilde dağıtılır (5 dakika).

5- $\quad$ Her grubu teker teker gezerek haritayı dikkate alarak arama yapmaları için yönergeler verilir. Grup içi yardımlaşma zemininin oluşmasını desteklenir. Belirlenen süre dolunca tüm gruplar düz alanda serili olan beyaz kumaşın üzerine alınır (10 dakika).

6- Buluntuları temizleme tekniklerini göstererek yaptırılır. Toplam Süre dolduktan sonra tüm sınıfı toplanarak çember şekli olunur. Her gruptan bir öğrenciyi çemberin ortasına alınır ve grupça seçtikleri objeyi göstererek neden seçtiklerini tüm arkadaşlarıyla paylaşır(10 dakika).

\section{DEĞERLENDIRME}

1.Her öğrencinin sürece katılıp katılmadığı öğrenci kontrol listesi ile değerlendirilir.

2. Öğrencilere yaptıkları etkinliğe ilişkin sorular yöneltilir:

a) Bu çalışmayı yaparken nelere dikkat ettiniz?

b) Uygulama esnasında en çok hoşunuza giden şey ne oldu?

c) Uygulama esnasında zorlandığınız bir konu oldu mu?

Tablo.7' de “Müzemi Oluşturuyorum” etkinliği için AHE ile oluşturulmuş ders planında temel beceriler, öğrenme alanı, kazanım, araç ve gereçler teknikler yöntemler duyuşsal ve düşünsel hazırlık detayları ile birlikte dersin AHE formatında işlenme süreci ve ders sonu değerlendirme esaslarına yer verilmiştir. Buna göre M.E. B. Müfredatındaki "Ülkemizin güzellikleri” adlı dersin kazanım ve öğrenme alanları açısından benzerlikler dikkate alınarak; "Müzemi Oluşturuyorum" etkinliği için AHE ile oluşturulmuş ders planı tasarlamıştır.

\section{Araştırmanın Uygulama Süreci}

AHEE öğrenci merkezli bir yaklaşım olduğundan öğrenciler açısından aktif bir öğrenme süreci sunmaktadır. Aktif öğreten öğretmenin diğer öğretmenlerden farkı; kendi kararlarını uygulamak yerine öğrencilere yön göstermek, önerilerde bulunmak, gerekli durumlarda açıklama yapmak, fikir vermek, rehber olmak ve onların gelişimlerini gözlemektir (Açıkgöz, 2014, s. 34). Aktif bir öğrenme süreci ancak deneyim, algı, biliş ve davranışın birlikteliği ile gerçekleşebilmektedir. Dolasıyla dersler gerek uygulama sürecinde gerekse dönüt evresinde öğrenci sorumluluğunda ilerler. AHEE'de de program için giriş gelişme ve sonuç bölümleri vardır. Bu bağlamda AHEE ile hazırlanan her ders: karşılama, uygulama ve değerlendirme olarak üç evrede gerçekleşmektedir (Gilbertson vd., 2005, s. 86). Aşağıda bu evrelere ilişkin bilgilere yer verilmiştir.

\section{Karşılama}

Gilbertson ve diğerlerine (2005, s. 58) göre AHEE'de en önemli basamaklardan biri de katılımcıları tanıma çalışmasıdır. Bu hem eğitici hem de katılımcılar bağlamında önemli bir basamaktır. Bu evrede aşama aşama gidilmesi önerilmektedir. Dolayısıla bilgi toplamada hiyerarşik bir yığın oluşturmanın faydalı olacağı öngörülmektedir. Bu kısımda araştırmacı tarafından birinci tekil ifadeyle uygulama süreci aktarılmıştır. Buna göre; araştırmanın karşılama evresinde alanda oluşturulan halka içinde uygulamalarla ilgili ön bilgilendirmeler yapılmıştır. Aynı zamanda öğrencilerde derse ilişkin merak uyandırmak amacıyla her uygulama için ayrı bir yöntemle ilgiyi odaklama çalışması yapılmıştır. Bu uyarıcı etki bazen konu bazen yaratıcı oyunlar bazen de ilgi çekici materyaller aracılığıyla yapılabilmektedir. Daha sonraki aşama gruplama aşamasıdır. Öğrencilerin aktif olduğu öğrenme türleri arkadaş ilişkilerini geliştirmektedir (Açıkgöz, 2014, s. 16). Bu doğrultuda öğrencinin etkin olduğu bir uygulama süreci içeren AHEE'de önerildiği üzere araştırmada grup çalışmaları esas alınmıştır. Gruplama aşaması katılımcılar için ilgi çekici bir yöntemle (öğrencilere kapalı poşet içinden rastgele seçtikleri renklere göre) yapılmıştır. Uygulamalar için gruplamada araç olarak küçük simgeler, işaretler ya da yiyecekler rastgele dağıtılarak öğrencilerin hangi gruba ait olduklarını belirleyen belirteçlere odaklanmaları sağlanmaktadır (Gilbertson vd., 2005, s. 86). Katılımcılar kendilerine sunulan farklı renklerdeki yapışkan kurdelelerden seçtikleri renklere göre gruplaştırılmıştır. Bu bağlamda katılımcıların temsil ettikleri grubun rengini üzerlerinde taşımaları sayesinde grup aidiyet bağı oluşturulmuştur.

\section{Uygulama}

Deneyimsel eğitimin ana teması sorumluluğun öğrencilere bırakılması esasına dayanmakla birlikte yönergelere uyum koşulu vurgulanmaktadır. Bu eğitim yaklaşımında öğrencilerin kendi yöntemleriyle yeni fikirler keşfederek öğrenme süreçleri için sorumluluk alması sağlanmaktadır (Robbins, 20015, s. 14). Fakat öğrenme sürecinin sorumluluğunun öğrencide olması öğretmenin 
sorumluluğunun bittiği anlamına gelmemektedir (Açıkgöz, 2014, s. 34). Dolayısıyla öğrenme sürecinde öğrencinin her istediğini yapması, öğretmenin karışmaması anlamı taşımamaktadır. Öğrencinin yaşayacağı muhtemel sorunlar için önlem almak öğretmenin sorumluluğundadır. Sonuç olarak öğrencinin aktif olduğu, öğrenmede öğretmenin rolünün değiştiği, bu rolün süreci tasarlama ve süreç sırasında danışmanlık yapmaya dönüştüğü söylenebilir. Açıkgöz’ e $(2014$, s. 48) göre öğrenciler öğrenme malzemesi üzerinde ne kadar çok konuşur, yazar, okur, gözler, değerlendirir ve eylemde bulunursa o kadar iyi öğrendikleri düşünülmektedir. Bu araştırmada uygulama süresince öğrenciler tüm etkinlikleri grup olarak gerçekleştirmiştir. Aktif öğrenme tekniklerinde, öğrencinin işe yaradığı duygusunu edinmesini sağlayan bir yöntem de gruplamadır. Özellikle işbirlikli öğrenmede eşit başarı fırsatı ilkesi, her grup üyesine roller verilmesi, herkesin başkan olması fırsatının bulunması gibi özellikler öğrencilerde işe yaradıkları duygusunu yaşatmaktadır (Açıkgöz, 2014, s. 51). Bu durum beraberinde öğrenciler arası dayanışmayı getirmektedir. Uygulamalar genel olarak grup olarak gerçekleştirilirken değerlendirmelerde yine grup olarak yapılmıştır. Açıkgöz'e (2001, s. 59) göre öğrencilerin aktif olduğu eğitim modellerinin dezavantajı, sorumluluk almaktan çekinen öğrenci tipinin sürece dahil olmakta zorlanmasıdır. Bu duruma çözüm olarak, uygulamalarda başarının da başarısızlığın da tüm gruba ait olması düşüncesinin oluşturulması yatmaktadır. Bu sayede öğrencilerde sorumluluk bilinci oluşacağı düşünülmektedir.

\section{Değerlendirme}

Öğrenciler yaparak-yaşayarak edindikleri deneyimlerinde kazanımlar kadar, sürece ilişkin bilişsel, duyuşsal ve devinişsel öğrenme çıktılarından kendilerine göre anlamlı bir sonuç çıkarmaları da önemlidir. Bu amaçla AHEE'de özetleme işlemi devreye girmektedir. Etkili bir özet, geri dönüp deneyime bakmayı, önemli dersleri çıkarmayı, bu dersleri genelleştirmeyi ve dersleri gerçek hayata uygulamayı içermelidir (Gilbertson vd., 2005, s. 134). Özetleme bir anlamda kavramayı da pekiştirmektedir. Kavrama işleminde öğrencinin bilgiyi yeniden üretmeye yönlendirilmesi esastır (Açıkgöz, 2001, s. 57). Gilbertson ve diğerlerine (2005, s. 132) göre AHEE' de nitelik olarak iyi sonuçlar elde etmenin üç sacayağı vardır. Bunlar deneyim, düşünme ve dönüştürmedir. Ancak bu evrelerin uygulandığı bir AHE gerçekleşme amacına tam olarak ulaşmış olacaktır. Bu anlamda öğrencinin uygulama evresi için aynı zamanda öğrenmeyi öğrenme evresidir denilebilir. Literatürde yer alan bu bilgiler ışığında her uygulama sonrasında öğrencilerin uygulamaya yönelik fikirleri, "Bugün ne yaptık?" sorusuyla alınmıştır. Aynı zamanda her uygulama sonunda bir öğrencinin derse yönelik geçen süreci özetlemesi sağlanmıştır. Böylece öz deneyim nitel araştırma ruhuna uygun bir şekilde aktarılmıştır.

\section{Verilerin Toplanması}

Araştırmalarda çoklu veri toplama tekniğinin kullanılmasında dikkat edilmesi gereken bir noktaya vurgu yapan Glesne' e (2013, s. 63) göre, çoklu veri toplama, verileri geçerlik ve güvenirlik bağlamında doğrulamak amaçlı kullanılan bir teknik değildir. Bu doğrultuda araştırmada kullanılan veri çeşitlemesi oluşturmak amacıyla dış-iç gözlemciler kullanılmıştır. İç gözlemci olarak sanat eğitimi alanından olan iki lisans öğrencisi belirlenmiştir. Dış gözlemcileri ise AHEE kullanan fen bilimleri eğitimi alanından gelen üç lisans öğrencisi oluşturmaktadır. Araştırmada veri toplama araçlarından; doküman incelemesi (Öğrenci günlükleri, gözlemci formları ve AHEE uygulama örneklerine ait yayınlar), yarı-yapılandırılmış görüşmeler (öğretmen ve odak öğrenciler) , video kayıtları ve görseller kullanılmıştır. Araştırmada doküman inceleme evresi üç veri toplama aracıyla gerçekleştirilmiştir. Bunların ilki öğrenci günlükleridir. İkinci araç ise dış ve iç gözlemcilere verilen gözlem formlarıdır. Uygulama öncesinde gözlemci olarak belirlenen öğrencilere bir uzman ve araştırmacı tarafından ayrı günlerde iki gün eğitim verilmiştir. Kullanılan üçüncü veri toplama aracı ise AHEE'ye ilişkin uygulama taslaklarını içeren yazılı metinlerdir. Bu metinler internet taraması yoluyla edinilmiş ve daha sonra çevirileri yapılarak incelenmiştir. Kullanılan veri toplama araçlarından bir diğeri yarı-yapılandırılmış odak öğrenci görüşmeleridir. Bu bağlamda sekiz odak öğrenciyle altı hafta süresince her uygulamadan hemen sonra görüşmeler yapılmıştır. Aynı doğrultuda ders öğretmeni ile de biri uygulamalar başlamadan önce diğeri sonra olmak üzere iki görüşme yapılmıştır. Görüşme sürecinin önemli unsurlarından biri sorulacak soruların niteliğidir. Son olarak tüm uygulamaların video kayıtları ve etkinlik görüntülerinin dijital ortamda dökümleri yapılarak veri niteliği kazandırılmıştır.

\section{Verilerin Analizi}

Nitel araştırmacılar nitel veri analizine farklı biçimlerde yaklaşmaktadırlar. Creswell'e (2013, s. 194) göre, veri analizi; amaç, metin ve imge verilerinden bir anlam çıkartmaktır. Creswell bu durumu veriyi bölümlere ve parçalara ayırmak (bir soğanın parçaları gibi) ve daha sonra tekrar bir araya getirmek şeklinde ifade etmektedir. Bu basamakta yapılan yarı-yapılandırılmış görüşmeler, gözlem notları, günlükler video kayıtları olmak üzere öncelikle tüm sesli ve görüntülü kaynaklar tekrar tekrar dinlenip izlenerek metin haline getirilmiştir. Daha sonra günlükler ve alan notları gibi defter üzerine aktarılan dokümanların dijital ortamda döküm işlemleri tamamlanmıştır. Görseller için düzenlemeler yapılarak her uygulama için bilgisayar ortamında birer görsel dosyası oluşturulmuştur. Ayrıca dijital ortamda kullanılacak bazı materyallerin dijital tarama işlemleri yapılmıştır. Araştırmada nitel veri analizi programı NVivo kullanıldığı için tüm veriler bu programa aktarılarak veri analizine hazır hale getirilmiştir.

Araştırmalarda çoklu veri toplama tekniğinin kullanılmasında dikkat edilmesi gereken bir noktaya vurgu yapan Glesne' e (2013, s. 63) göre, çoklu veri toplama verileri geçerlik ve güvenirlik bağlamında doğrulamak amaçlı kullanılan bir teknik değildir. Bu doğrultuda araştırmada kullanılan veri çeşitlemesi de özellikle dış ve iç gözlemciler aracılığıyla toplanan veriler konusunda geçerlik güvenirlik sağlamasından öte AHEE' nin açık alanlarda geçen bir uygulama sürecine dayalı olması ve araştırmacının da uygulamanın içinde yer alması nedeniyledir. 


\section{Verilerin Tamamının Okunması}

Bu aşamada ise her uygulama sonrası dökümü yapılan kayıtlar ve dokümanlar okunarak parçadan bütüne doğru gidilmiştir. Nitel veri araştırmacılarının önerdiği şekilde durum çalışması gibi desenlerin kullanıldığı derinlemesine inceleme çalışmalarında tekrar başa dönüp okuma eylemi gerçekleştirilmiştir (Glesne, 2013, s. 143). Görseller için ise görsel gösterge bilimsel bir yaklaşımla görsel ve metin arasında ilişki ağı oluşturulmuştur. Bu bağlamda araştırmada veri analizi için hazır hale gerilmiş veri seti toplamı Tablo 8.' de gösterilmiştir.

Tablo 8. Araştırmada kullanılan nitel veri seti

\begin{tabular}{|c|c|c|}
\hline Nitel Veri Çeşitleri & Veri Kaynağı - Materyal & $\begin{array}{l}\text { Veri Dökümü } \\
\text { (Sayfa) }\end{array}$ \\
\hline Doküman & $\begin{array}{l}\text { 2015-2016 Eğitim öğretim yılı 5. sınıf Görsel Sanatlar Dersi ünitelendirilmiş yıllık } \\
\text { planı }\end{array}$ & 6 sayfa \\
\hline Görüşme Dökümleri & $\begin{array}{l}\text { Sekiz odak öğrenciyle yarı -yapılandırılmış görüşme dökümleri. Ders öğretmeni ile } \\
\text { yapılan ön-son görüşme dökümleri }\end{array}$ & 132 sayfa \\
\hline Video Dökümleri & $\begin{array}{l}\text { Altı hafta süren her bir uygulama için bir ders saati süresince kayıt edilen görüntü } \\
\text { dökümleri }\end{array}$ & 28 sayfa \\
\hline \multirow{2}{*}{ Dış-iç Gözlemci Formları } & Kategorik gözlem formu dökümleri (EK 13) & 19 sayfa \\
\hline & Saha notları formu dökümleri (EK14) & 25 sayfa \\
\hline \multirow{2}{*}{ Araştırmacı Notları } & Araştırmacı günlüğü dökümü. & 13 sayfa \\
\hline & Pilot uygulama notları dökümü & 8 sayfa \\
\hline Toplam & & 231 sayfa \\
\hline
\end{tabular}

Tablo 8.' de verildiği üzere dokümanlardan 6, görüşmelerden 132, video dökümlerinde 28, dış ve iç gözlemci formlarından 41 ve araştırmacı notlarından 21 olmak üzere toplam 231 sayfa dökümü yapılmış veri NVivo programına aktarılmıştır. Daha sonra bütün verilerin kodlama öncesi ve sırasında okumaları yapılmıştır.

\section{Verilerin Betimsel Analizinin Yapılması}

Araştırmada kullanılan verilerin hazırlık evresinde birinci ve ikinci basamaklarının açıklandığı nitel veri analizi hiyerarşik işlem basamaklarının geri kalan kısımları bu bölümde açıklanmıştır. Kodlama: Veri toplama süresince toplanan veri veya resimlerin metne aktarımını, kategorilerin imgelere veya cümlelere (veya paragraflar) ayrıştırılmasını ve genellikle de katılımcının güncel diline dayalı bir terim ile bu kategorilerin isimlendirilmesini içermektedir (Creswell, 2013, s. 198). Kodlama aşamasında, araştırmacı tarafından detaylı okumaların ardından araştırma sorularını işaret eden ve araştırma sorularıyla bir bağlantısı olmamasına rağmen bir olgu olarak ortaya çıkan kısımlar da kodlanmıştır. Daha sonra oluşturulan kod- tema dosyaları bir alan uzmanı tarafından detaylı bir şekilde incelenmiştir. Bu doğrultuda birbiriyle ilişkili ifadeler ortak temalar altında toplanırken metin/ görsel, tema ve kod ilişkileri gözden geçirilmiştir. Elde edilen temaların alt başlıkları ise alt temaları oluşturmuştur. Oluşturulan temalar ve alt temalar karşılaştırılarak görüş birliğine varılan temalar aynı kalırken, görüş ayrılı̆ı yaşanan bölümler yeniden düzenlenmiştir. Tema geliştirmedeki son aşama, temaların tam olarak geliştiği ve yeni kanıtların ek temalar sağlamadığı bir noktaya ulaşmaktır. Araştırmacının bu doyum noktasına ulaştığını fark etmesi öznel bir değerlendirmedir (Yurdakul vd., 2016, s. 16 ). Bu bağlamda araştırmanın iç geçerliliğinin sağlanması amacıyla verilerin elde edildiği kaynaklar, verilerin çözümleme aşaması açık ve ayrıntılı olarak hem manuel olarak hem de kullanılan nitel veri analiz programı kanalıyla rapor edilmiştir. Böylece araştırma bulgularının kolaylıkla sınanmasının yolu açılmıştır. Elde edilen kod, tema ve kategoriler yalın veriler üzerinden tekrar okunmuş olup daha sonra araştırmacı dışındaki bir uzman tarafından incelenmiştir. Nitel veri analizindeki son basamak bulguların yorumlanmasıdır. Bu araştırmada yukarıda bahsedildiği üzere literatür ya da teoriden derlenen bilgi ile bulguların karşılaştırılmasından türetilen bir yol izlenmiştir. Bu amaçla ilk aşamada verilerin analiz edilmesinde ön hazırlık yapılarak veriler betimsel analiz tekniğiyle analiz edilmiştir. Bulguların yazılmasında ve yorumlanmasında diğer veri toplama araçlarından elde edilen sonuçlardan doğrudan alıntılar yapılarak literatürle bağlantılı bir biçimde yorumlanmıştır. Araştırmada elde edilen bulgulara göre araştırmacı kendi görüşlerini de yansıtmıştır.

\section{BULGULAR}

Araştırmanın bulguları kapsamında elde edilen temalar: Görsel ifade, Eleştirel ifade ve Kültürel ifade, olarak belirlenmiştir. Buna göre: Görsel ifade temasına ilişkin alt temalar: Yaratıcı fikir geliştirme, iletişim kurma, yansıtma yapma ve imgesel düşünme olarak belirlenmiştir. Eleştirel ifade temasına ilişkin alt temalar: özeleştiri yapma, farklı düşünceye saygı duyma, değerlendirme yapma ve öneri sunma olarak belirlenmiştir. Kültürel ifade temasına ilişkin alt temalar ise: kültürel mirasa değer verme, sanatçıyı anlama, sanat eserini algılama ve doğaya saygı duyma olarak belirlenmiştir

\section{Görsel ífade Temasına iliş̧kin Bulgular}

Sanatsal düzenleme ilkelerinin seçilen etkinlik, yöntem ve teknikler eşliğinde; bilişsel, duyuşsal ve devinişsel kazanımlara yönelik uygulamalar içinde geliştirildiği ve pekiştirildiği öğrenme alanına görsel iletişim ve biçimlendirme denilmektedir (Pekşersoy 
ve Yıldırım, 2008, s. 12). Görsel iletişim ve biçimlendirme alanı için; bilişsel, duyuşsal ve devinişsel öğrenme alanlarının sanat eğitimi ilke ve prensipleriyle harmanlanmış olması önerilmektedir. Dolayısıyla her sanatsal edimde olduğu gibi ortaya konulan kompozisyonun birtakım öğrenme alanlarının aktifliği sayesinde yaratıcı bir eyleme dönüşebileceği düşünülmektedir. Bu doğrultuda elde edilen görsel ifade teması görsel iletişim ve biçimlendirme temel öğrenme alanına dayanmaktadır. Görsel ifade temasına ilişkin elde edilen alt temalar: yaratıcı fikir geliştirme, iletişim kurma, yansıtma yapma, imgesel düşünmedir. Bu alt temaları oluşturan kodlar ise Şekil 2' de gösterilmiştir.

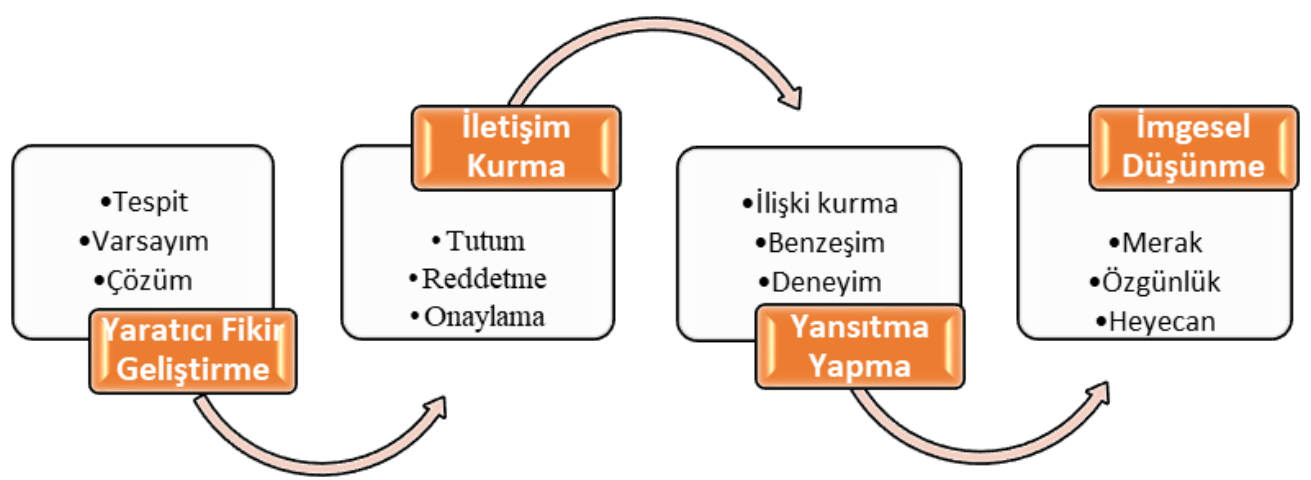

Şekil 2. Görsel ifade temasına ilişkin alt temalar ve kodlar

Görsel ifade temasına ilişkin alt temalar ve kodlardan elde edilen bulgular aşağıda ayrıntı olarak açıklanmıştır.

\section{Yaratıcı fikir geliştirme alt teması}

Uygulamaya yönelik düşünme, öğrenmenin sınıftan dışarı adım attığı ve öğrenilenlerin gerçek hayatla ilişkilerinin kurulmaya başladığı evredir (Özden, 2014, s. 152). Öğrencilerin yaşamın gerçekliği içinde zorlu şartlar için çözüm arayışları geliştirmelerini sağlamak bir bakıma onlara düşünsel sürecin kapılarını aralamaktadır. Bu bağlamda yaratıcı fikir geliştirme alt teması AHEE ile yapılandırılmış uygulamaların temelinde yer alan $3 \mathrm{H}^{4}$ kuralının sürece nasıl yansıdığı izlenmiştir. Yaratıcı fikir geliştirme, öğrencinin bir sorunla karşılaşması halinde aktif olabilen bir durumdur. Dolayısıyla sorunun çözümü, ancak çözümcü fikirler üretebilmekle mümkün olabilmektedir. Çözümcü fikir üretme eylemi diğer adıyla çözümleme eylemidir. Kavram olarak çözümleme ise duruma yönelik düşünme olarak açıklanabilir. Bir diğer ifadeyle çözümleme, öğrencinin bilgi ve becerilerini bir durumu çözüme kavuşturma çabasıyla kullanmasıdır. Öğrenciler uygulamalarda durum üzerine fikir yürütme evresinde kendilerince öneriler ve çıkarsamalarda bulunmuşlardır.

"Hızlı düşündük çünkü uygulama yaparken süremiz vardı. Mesela tarihi bir şey seçip onu şey yaparken süremiz vardı. Süreyi kullanma üzerine düşündüm ben." (Melda)

Farklı olanı bul adlı derste geçirilen düşünsel sürece ilişkin değerlendirme yapan Zafer, herkesin farklı bir fikrinin olduğu kanısına vardığını ve bu fikirlerin paylaşımı sayesinde yaratıcı fikirler edinmesine imkân tanındığını vurgulamıştır.

"Cidden çok yaratıcı fikirler üretmiş olduk. Üç takıma ayrıldık ve herkes farklı farklı fikirlerini ortaya koyarak dört farklı nesneden dördünün de farklı yönlerini bulduk. Cidden bir nesnenin yani ikisi aynıysa bile biz farklılıklarını bulabiliriz. Çok küçük ayrıntı dahi olsa bu bir farklılık oluyor. Bu yüzden bu etkinliği yapma amacınızın bu olduğunu düşünüyorum. Bizim daha yaratıcı fikirlerimizi öğrenmemiz yani birbirimizin fikirlerini okuyamadığımı için bilemedik ama değişik fikirler görmüş olduk. Herkesten farklı fikirler çıktı. Hepsi doğruydu ama o takımın seçtiği farklı bir cevaptı. Dört nesne arasında yüzlerce binlerce farklılık bulunabildiğini görmüş olduk." (Zafer)

"Öğrencilerin uygulamalarda çoğunlukla fikir yürütmelerine ilişkin görüşleri yansımıştır. Derslerin açık alanda yapılmasının kendilerinde hem derse hem de akran ilişkilerine motive edici bir etki uyandırdığını vurgulamışlardır. "Açık ortamdayız, üstümüz kapalı... iki duvar, dört duvar arasında ders işlemiyoruz hem de eğlenceli bir anda şunu mu seçsek bence bunu anlarlar diye tartışıyoruz birbirimizle öyle."(Ali)

Gözlemci saha notları ve öğrenci görüşlerine yansıyan gözlemlere göre öğrencilerin zorlu durumlarda problem çözmeye ilişkin olarak çaba sarf ettikleri vurgulanmıştır. "Hava şartları çok uygun olmadığı halde çocuklar ortama hazırlıklı ve ayrıca çözüm yolu bulmaya çalıştılar." (Cansu, dış gözlemci)

"Mesela şöyle bir şey de var: Kartonları koyduğumuzda uçuşuyorlardı. Ayrıca sorunlara çözüm üretmeyi öğrendik. Zorluklarla karşılaştık ve bunlar için çözüm ürettik. Hem de resim etkinliğiyle ilgili pek çok şey öğrendik." (Zafer)

\footnotetext{
${ }^{4}$ Açık Hava Eğitimi Modelinde Scots Polymath ve Sir Patric Cteddes'in modelin yapıtaşı olarak ön plana çıkarttıkları "3H” (Heads, Hand, Hearts) kavramı da esasen

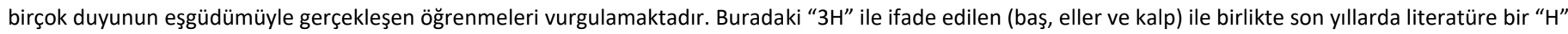
daha eklenerek Holistik düşünme kuramı da işe koşulmuştur. Böylece amaçlanan okuldaki yalın düşüncenin karşısında bulunan özel okul dışı ortamlardaki araç kullanımıdır. Okulda, özellikle değerlendirme sürecinde yalın düşünce etkinlikleri bireylerin kitapsız, notsuz, hesap makinesiz ve diğer karmaşık enstrümanlar olmaksızın neler yapabileceği olduğunu belirtmiştir. Bu durumun karşıtı ise, insanların okul dışında karşılaştıkları ve araçlarla ilgili olan bilişsel etkinliklerdir. Bir diğer ifadeyle, düşünce ve sorun çözme süreçleri ürünlerin uygun araçlarla olan etkileşimidir (Ataizi ve Şimsek, 1999, s. 263).
} 
Uygulamalarda gerçekleşen, grup olarak fikir yürütme eylemi konusunda iki bakış açısı üzerindeki yansımalar dikkat çekicidir. "Gruplu olunca birçok kişinin istediği yapıt oluyor ve hepsi farklı farklı oluyor. Sonucunda daha güzel daha değişik fikirlerle daha yaratıcı bir yapıt ortaya çıkıyor. Bunun için grupla yaptığımızda biz de sorun yaşadık. Mesela şu taş... Farklı farklı taşlar bulduk. Birisi farklısını istedi, birisi farklısını istedi ama aramızda oylama yaparak karar verdik ve en güzelini oluşturmayı başardık." (Zafer)

\section{iletişim kurma alt teması}

Görsel ifade teması bağlamında elde edilen alt temalardan biri iletişim kurmadır. Bu alt temayı oluşturan kodlar öğrenciler arasında akran ilişkileri ve öğretmen öğrenci ilişkileri etrafında toplanmıştır. Tutum için, olaylar karşısında hissedilen etkiye gösterilen tepki ile meydana gelen duygu durumu denebilir. Bu kod, özel gereksinimli (yarı kaynaştırma alan öğrenci) bir öğrenci olmasına karşın, gönüllü olarak odak öğrenciler arasında yer almak isteyen Nuray'dan gelen verilerden elde edilmiştir. Nuray'ın bazen kendi bazen de arkadaşlarının gösterdikleri tutum karşısında görüşmelere yansıyan ifadelerinde grup olarak çalışma konusundaki kaygıları saptanmıştır. Uygulamaların bu aşamasında Nuray arkadaşları tarafından kabul edilmeme ve dışlanma duygusunu vurgulamıştır.

“Çok güzel bazen ama şey aynı takım arkadaşlarıyla olunca o kadar güzel olmuyor. Bazen şey... Arkadaşlarımda sanırım mutsuz oldu benim o takıma girdiğime azıcık ama. Onlar belirtmemeye uğraştılar kesin ama yine de olsun." (Nuray)

Nuray, derslere devam ettikçe kendisine yardımcı olan arkadaşlarının değişen tutumunu hissettiğini vurgulamıştır. Bu değişimin uygulamalarda işleyişin grup etkinliğine dayanması sonucu olduğu düşünülmektedir."...Çok mutlu oldum ve çok sevindim. Eğer yardımcı olmasalardı asla yapamazdım. Benim bildiğime göre ben öyle hissediyorum.” (Nuray) Öğrencilerin grup halinde eyleme geçmelerinin arkadaşlıklarını pekiştirdiği konusu Tuna tarafından vurgulanmıştır. "Yine birlik içindeydik, takımımız vardı. Bundan dolayı hem birlikteliğimizi güçlendirdik arkadaşlarımızla hem de bir birazcık daha fazla bilgi öğrendik." (Tuna) Zafer ise grup dayanışmasını takım ruhu şeklinde adlandırmıştır; “...Son olarak da takım ruhu ortaya çıkmış oldu çünkü hep birlikte bir bilgi için uğraştık yani bir on- yirmi dakika bunun için uğraştık ve sonucunun çok güzel olduğunu düşünüyorum. Uğraştığımıza değdi." (Zafer)

\section{Yansıtma yapma alt teması}

Öğrencilerin yansıtıcı düşünceyi hem uygulamalarda etkinliği gerçekleştirirken hem de uygulama sonucunu değerlendirirken kullandıkları görülmektedir. Bu bağlamda biriken kodlar çerçevesinde yansıtma yapma alt teması ortaya çıkmıştır. Odak öğrencilerin yansıtma yapmada esas olanın Kırışoğlu'nun $(2005$, s. 192) da belirttiği üzere çevre kaynaklı taklit olduğuna dair ifadeler yer almıştır.

"Yani normalde o kadar da çok takmam ama böyle çok ilgimi çeken bir şey olursa ona bakarım ve o sesi taklit etmeye çalışırım. Çünkü şahsen sesimi güzel buluyorum ve bunu değerlendirmek için güzel bulduğum bir sesi hemen taklit etmeye çalışırım."(Melda)

Öğrenciler yansıtmaları uygulamadan dışarıya (gündelik yaşama) yaptıkları gibi bazen de dışarıdan aldıklarını içeriye (uygulamalara) yansıttıklarını ve bunu başarılı olmak için kullandıkları ifadelerine rastlanmıştır.

"Yani çoğunun ne malzemeden yapıldığını biliyordum çünkü bu konuda deneyimliyim. Ee şimdi bunları teker teker anlatırsam bayağı şey olur. Bakırın nasıl göründüğünü bilirim, bakır hakkında deneyimim yoktur ama bakırın nasıl bir şey olduğunu bilirim. Çünkü yani elektronik şeylerin içini açıp bakmayı çok severim. O zaman da bakır tellerden o rengi bilirim. Bakırın rengi kendine hastır. O yüzden her zaman bakırı görürsem anlarım bunun bakır olduğunu tabi boyanmamışsa." (Melda)

Dewey'e (2007, s. 23) göre bütün prensipler kendi başlarına soyut kavramlardır. Ancak ve ancak hayata geçirilmelerinden sonra ortaya çıkan sonuçlarla somutlaşırlar. Öne sürülen prensipler öylesine temel ve geniş kapsamlıdır ki her şey bunların okulda ve uygulanması esasında nasıl yorumlandıklarına bağlıdır. Dolayısıyla çocukların öğrenmelerinde yansıtmanın oldukça önemli olduğu düşünülmektedir. Her yansıtma öğrenme sürecinde gerçekleşen yorumlama ve yordama ürünüdür diyebiliriz. Ayrıca her yorumlama kendi içinde bireysel farklılıklar oranında değişir ve şekillenebilir. Bir gereci olanak sınırlarını zorlayarak farklı biçimde kullanmak, bir konuya herkesten farklı biçimde yaklaşmak, bir çalışmada sorun çözerken yeni yollar bulmak çocuklarda yaratıcılık olarak tanımlanabilen davranışlardır (Kırışoğlu, 2014, s. 16). Aşağıda Melda'nın tarif ettiği şekliyle durumu diğer arkadaşlarının yaklaşımından tamamen farklı bir açıdan ele alması bir bakıma Kırışoğlu’nun değindiği durumun örneğidir.

“Aslında ben daha çok o şeyin ses konusuyla ilgilendim. Diğer arkadaşlarım dokusuna falan baktı, böyle eliyle kaldırdı. Ben yere vurdum, hepsini teker teker yere vurdum. Aslında kırılmasında biraz korktum ama yere vurdum ve fen bilgisinde şey yaptıklarım aklıma geldi." (Melda)

Burada Melda fen bilgisi dersinde öğrendiği ve deneyimlediği bir bilgiyi karşılaştığı yeni durumu çözümleme amaçlı kullanmıştır. Dolayısıyla hazır bilgisini yeni duruma yansıtmıştır. Somut bir sorunla karşı karşıya kalan öğrenciler çözüm arayışlarında önce ilgilerine yönelik bellek şemalarından çağırdıkları bilgilere dair çağrışımlar yakalamaktadırlar. Bu arayışın bir diğer adımı ise benzeşimler kurmaktır. Böylece daha önce deneyip ya da temas edip sonuç aldıkları durum bir anlamda yeni sorunun çözümünde kılavuz niteliğini taşımaktadır.

“...Çünkü yani bazı etkinliklerde beyin fırtınası yapıyoruz, matematiğimizi güçlendiriyoruz. Ondan sonra tabi bunları yaparken resmimizi de çok ilerletiyoruz. Bazı etkinlikleri yaparken sosyal bilgilerimizi de güçlendiriyoruz. Yani mesela İzmir, Ege bölgesi, İzmir Saat Kulesi bu sosyal bilgilerle alakalı bir şey ve biz bunu resim yaparak güçlendirdik. Yani gerçekten ben bu bilgileri ilerde kullanacağım. Gerçekten çok güzel bir etkinlikti." (Tuna) 
Uygulamaları Görsel Sanatlar Dersi bağlamında değerlendiren öğrencilerin kurdukları disiplinler arası ilişki sayesinde dersin amaç ve hedefleri konusunda birtakım yargılarda bulundukları saptanmıştır.

“...Müzik dersinde olan bir etkinliği, sosyal dersinde olan bir etkinliği ve matematik dersinde olan bir etkinliği resim dersi içine getirdik. Bence bu çok güzel oldu bizim için çok beğendim. Bazen Türkçe derslerinde yine din derslerinde değişik derslerde öğrendiğimiz konularla ilgili şiir yazıyorduk. Resim dersinde de şiir yazılabileceğini öğrenmiş olduk." (Zafer)

Kırışoğlu'na (2005, s. 100) göre "Sanat öğretimine olumsuz yaklaşımlar, bilimle sanat, zekâ ile yetenek, biliş ile duyuş arasına çekilen keskin çizgide somutlaşır. Oysa sanatın salt sezgiyle ya da duyuşsal alanla ilgili olduğu görüşü günümüzde romantik bir yaklaşımdan öte gerçekliğini yitirmiştir." Sayısal alana dayanan dersler matematik, geometri vb. dersler ile sosyal alana dayanan Türkçe, Sosyal Bilgiler vb. gibi derslere ait bilgilerin Görsel Sanatlar Dersi'nde kullanılması öğrenciler tarafından vurgulanmıştır.

"Bizim bu sene ve geçen sene işlediğimiz bir konu var. Hep işliyoruz bunu: ışıkla ses. Onun ses konusunda bu sene yankı, onu da öğrenmiştik. Sonra yere vurunca böyle aklıma bir canlandı böyle. Yani Fazıl Hocam, benim fen bilgisi öğretmenim oluyor...He işte, o aklıma geldi işte. Böyle yankıyı falan anlatırken, böyle kuytu köşe bir yerde içinde neredeyse hiçbir şey olmayan boş bir adaya gidip bağırdığınızda sesiniz yeniden size yeniden gelir." (Melda)

\section{İmgesel düşünme alt teması}

Öğrenciler uygulamalardan sonra düşünsel anlamda ve algıda yaşadıkları değişimi cümlelerine dökmüşlerdir. İpşiroğlu' na $(2015$, s. 6) göre öğrencilerin büyük çoğunlukla yakındığı dersler ezbere dayanan kuramsal derslerdir. Öğrencilerin, kendilerini doğrudan etkinliğe yönlendirecek bir ders sistemi istemeleri ve ezberciliğe karşı tavır almaları kendilerini geliştirme ve öğrenme gizil güçlerinin sanıldığı kadar düşük olmadığının en çarpıcı kanıtıdır. Bu bağlamda neredeyse tüm odak öğrenciler duygularını aktarırken Tuna'nın ifade ettiği: "Biz çocuğuz ve oyun oynayarak daha iyi öğreniyoruz". (Tuna) fikrini savunmuşlardır. Aktif bir eğitim süreci geçiren öğrencilerin bunun doğal sonucu olarak imge dünyalarının besleneceği düşünülmektedir. Müzemi oluşturuyorum adlı derste teorik bir müze bilgisinden öteye geçilerek bir müzenin var oluşunu yaşantılamaları sağlanan öğrencilerin bu derse ilişkin görüşleri onların imge dünyalarının harekete geçtiğini göstermektedir.

"Yani müze deneyimim oldu. Cidden çok güzel. Ee aslında müze deyince akla kocaman bir yer gelmemeli, bir müzede kendimiz yapabiliriz mesela evimize. Ee küçük bir kutu yaparız. İçine bulduğumuz çeşitli taşlar olabilir, çeşitli malzemeler olabilir. Bunlardan güzel bir müze oluşturabiliriz kendimize." (Zafer) Zafer'in ifadelerine yansıyan müze tanımı tamamen kendi imgesinde canlandırdı̆̆ı bir üründür. Özellikle 9-11 yaş aralığında katı gerçekçilik döneminde bulunan çocukların resimlerinde daha ayrıntılı çizimler ve gerçekçi bir yaklaşım görülür (Yavuzer, 2000, s. 65) . Zaferin imgesinde canlandırdığı müzenin küçük bir kutu ve taşlardan oluşmasının altında da benzer sebeplerin yattığı düşünülmektedir.

"Farklı olanı bul, burada bizim daha çok yaratıcılı̆̆ımızı kullanmamızı sağladı. Mesela evde de birçok nesnemiz var. Biz de bunlarla farklı olanı bul etkinliği, farklı olanı sen seç gibi bir oyun düzenleyip yapabiliriz. Dışarıdan oyunlar almak yerine böyle oyunlar kendimiz de üretebiliriz." (Zafer)

Çalışma sürecinde duyulara yansıyan görüntü ile üretenin usundaki imge ya da imgeler arası ilişki kurma çabası sürer. Bu ilişkiyi kurarken kişinin kendi çıktılarının, değiştirilerek ve öğrenilerek yine üreteni yönlendirmesiyle gelişen sistem sürekli işler. Bu dinamik, kendi kendine öğrenme davranışının tipik örneğidir (Kırışoğlu, 2005, s. 109). Uygulamaların öğrencilere yansıyan başka bir boyutu ise imgeyi kodlama ve imgesel süreklilik üzerine betimlemelerde bulunmaları olmuştur. Melda yaparak-yaşayarak edindiği deneyimin kendisinde kalıcı izler bıraktığına vurgu yapmıştır. "Mesela doğaya baktığımda, ağaçlara falan baktığımda belki de aklıma bu etkinlik gelecek. Sonra mutlu olacağım hatta belki anneme anlatmayı unutmuş olup anneme o zaman ne yaptığımı anlatacağım. İşte ondan sonra doğada mesela ilginç bir şey görünce ben bunu tişörtüme yapabilirim. Bu güzel olur diye düşüneceğim belki....Yani evde bir oturdum düşündüm işte böyle yani biraz daha şey yaptım böyle mesela o kadar daha şimdi hayalimde canlandırdım o yaptığım şeyi. O kadar da kötü olmamış aslında." (Melda) Uygulamaların dışarıda olması ve dersin bir oyun şeklinde işlenmesinin verdiği coşkuyla öğrenciler, genelde olumlu yargılarda bulunsalar da görüşmelerde olumsuz düşüncelerin paylaşılması için de rahat ortam yaratılmaya çalışılmıştır.

\section{Eleştirel ifade Temasına iliş̧kin Bulgular}

Sanat eleştirisi, bir sanat eserini eleştirmek ve o esere karşı duyarlı bir tepki verme süreci olarak tanımlanır. Bu bağlamda eleştirel ifade temasına ilişkin alt temalar: özeleştiri yapma, farklı düşünceye saygı duyma, değerlendirme yapma ve öneri sunma olarak belirlenmiştir. Belirlenen alt temalara ilişkin kodlar Şekil 3.' de verilmiştir. 


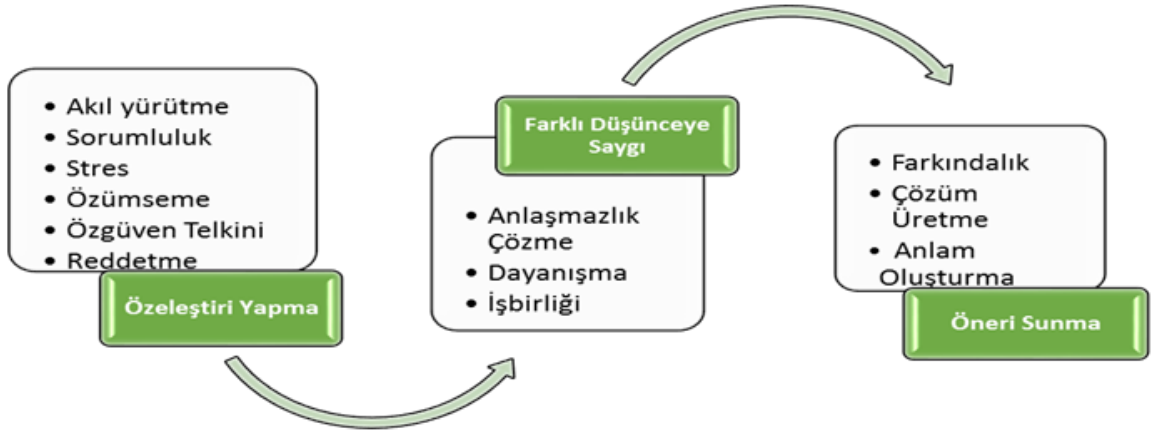

Şekil 3. Eleştirel ifade temasına ilişkin alt temalar ve kodlar

Eleştirel ifade temasına ilişkin alt temalar ve kodlardan elde edilen bulgular aşağıda ayrıntılı olarak açıklanmıştır.

\section{Özeleştiri yapma alt teması}

Her uygulama sonrası yapılan odak öğrenci görüşmelerinde öğrencilerin kendilerine yönelik özeleştiri yapmalarına ilişkin bulgulara rastlanmıştır. Öğrencilerin yaptıkları eleştirilere yönelik sabır, sorumluluk ve stres gibi kodlar elde edilmiştir. Bu kodlar özeleştiri alt teması çerçevesinde toplanarak yorumlanmıştır. Özeleştiri alt temasına ilişkin en çok veri edinilen öğrencilerden biri yarı kaynaştırma öğrencisi olan Nuray'dır. Nuray görüşmelerde sağıı problemlerinin farkında olmasına karşın kendi durumunu diğer arkadaşlarından ayırmaksızın eleştirmiştir. Uygulama kuralları gereği yapması gereken işlemin hızlı olması gerektiğinin farkında olduğunu vurgulamıştır. İşlemleri yapılması gereken şekilde yapamadığını belirterek kendini eleştirmiştir.

“Normalde ben çok eğlendim. Hızlı olması da çok eğlenceliydi o. Orda acayip sevinçliydim, mutluydum. Ellerimi boyaya batırmak çok eğlenceliydi. Özellikle basmam zordu zaten. Hızlı yanlış yere basıyordum çünkü ben zaten hızlı bir yere basamıyorum. Oldukça yavaş basabiliyorum." (Nuray)

Turan müzemi oluşturuyorum dersinden sonra müzelerle ilgili bilgisi ve bakış açısına yönelik bir eleştiride bulunmuştur. Artık bir müzeye gittiğinde o müzenin nasıl oluşturulduğunun farkındalığıyla yaklaşım sergileyeceğini vurgulamıştır. "Müzeye gittiğimde artık bunların nasıl çıkartıldığını ve ne kadar kaç gün süren bir çalışmanın sonucunda çıktığını, ondan önce de bunun yapılırken nasıl yapılıp oraya girdiğini daha çok düşüneceğim. Daha iyi bir fikir oldu aklımda. Bunları öğrendim güzeldi." (Turan) Adnan ise düşünme şekline yönelik olarak kendini az düşündüğü konusunda eleştirmiştir. Bu dersten sonra düşünme alışkanlığının değiştiğini vurgulamıştır. "Azıcık düşünüyordum. Çok fazla düşünmüyor, çok fazla düşünmüyordum ama şimdi bu etkinlikten sonra artık konular hakkında daha çok düşünüyorum." (Adnan)

Yukarıda Adnan'ın vurguladığı durum bir bakıma Piaget'in savunduğu özümseme kavramını açıklamaktadır. Özden'e (2014, s. 58) göre Piaget, bilginin bireyin çevresi ile aktif olarak etkileşimi sırasında ortaya çıktığını varsaymaktadır. Melda'nın ifadesinde geçen “Doğaya baktı̆̆ımda, ağaçlara falan baktığımda belki de aklıma bu etkinlik gelecek." ve Ali'nin ifade ettiği “ Bu etkinlikten sonra mesela şuradaki ağaca bakınca bunu neden buraya koymuşlar diyebiliyorum." Piaget'in birey, karşılaştığı yeni durumu eski bilgi ile ve deneyim yardımıyla tanımlamaya yani özümlemeye çalışır, şeklindeki açıklamasına örnek teşkil ettiği düşünülmektedir.

Akıl yürütme etkinliği bir diğer adıyla düşünme eylemidir. Düşünme esas alındığında öğretim, içerik ve yöntem olarak öğrencinin açıklama, sentezleme genelleme ve hipotez geliştirme yoluyla bilgi ve fikirleri manipüle etmesine yönelik olarak düzenlenir (Özden, 2014, 27). Bu duruma örnek olarak Melda'nın: "Mesela bunda da aslında bir simetri var bence, doğal olarak çünkü aslında biraz neden sonuç gibi. Çekici hızlı vurursan tişörtün delinir." (Melda) ifadesi gösterilebilir.

Öğrencilerin ders esnasında bir oyun kurucu gibi davrandıkları ve ders sonrasında kendilerini eleştirdiklerine yönelik yansımalara rastlanmıştır. "Doğru karar vermek için acele etmeden bir işlem yapmamız gerektiğini anlıyorum. Yani doğru yola gitmenin birçok yolu var. Bazen hız bazen de acele etmemek bazen sabır ve bazen çok farklı şeyler." (Zafer) Başka bir bakış açısıyla Zehra ise: "Orda da yine mantığımızı kullanma olabilir. Yani mantığımızı kullanarak ölçüm yaparak, e bunu halledebiliriz. Ardından temizleme yaptık, bu da bende şöyle bir ilgi uyandırdı. Ben de evde gidip mesela şöyle bir oyun geliştirebilirim diye." (Zehra)

Öğrencilerin eleştirel yaklaşımının bazen de değerlendirme boyutunda olduğuna rastlanmıştır. Buna göre Zafer aynı ders içinde hem yarış hem sınav hem de eğlence duygusunu yaşadıkları konusunda vurgu yapmıştır. "Kendimizi denedik. Daha böyle hırsla bir yarışma yapmış olduk. Yani kendimizi ölçmüş olduk. Bir nevi bir resim sınavına girmiş olduk Hem bilgimizi ölçtük hem dayanışma kurduk en önemlisi de eğlendik." (Zafer)

Güdelemenin içten yapılması örneğine Melda'nın ifadelerinde rastlanmıştır. Melda kendi sürecini hayranı olduğu bir bilim insanının yaşadığı bir sürece benzeterek, benzer tepki verme duygusunu vurgulamıştır. "Ve zaten o yankı olayını ben buldum ve bulur bulmaz da "Evraka!" diye bağırasın geldi. Yani o bir onun bir hikâyesi var. Arşimet o suyun kaldırma kuvvetini bulduğunda "Evraka!" diyerek şey yapmış." (Melda)

Öğrencilerin yapmış oldukları özeleştiri kapsamına giren bir diğer kavram güvendir. Kendine güven üzerine yapılan tespitlerde güven eksikliğinin sebebini korku ve strese dayandıran Zafer daha cesur olmak konusunda çıkarımlarda bulunmuştur. "Olumsuz yönleri ise kendimiz için bu sadece özen olarak kendimizin bazı kötü yanlarını görmüş olduk: stres, korku... Yani daha cesur olmamız gerekiyor ve kendimize güvenmemiz gerekiyor." (Zafer) 
Beşinci uygulamada kasıtlı olarak öğrencilerin sabır konusundaki tutumları irdelenmiştir. Bu bağlamda Melda'nın kendine ve uygulamaya yönelik eleştirisinden yansıyan düşünceleri ise daha çok olumsuz yönde olmuştur. Bunun yanı sıra Melda kendini sabırsızlık konusunda eleştirmiştir. "Olumlu yönleri yani sonunda güzel bir şey ortaya çıktı ama olumsuz yönleri yani benim için çok fazlaydı. Çünkü geçen şeyde de demiştim saman çöpü gibi. Saman şey... Saman alevi gibi sinirlenince böyle çok çabuk sinirleniyorum. Sakinleşirim ama bu sefer sinirleniyorum. Sakinleşiyorum sonra kazıyorum gene sinirleniyorum gene sakinleşiyorum gene kazıyorum. Yani öyle bir durum oldu." (Melda)

Özgüven telkini konusunun öğrenciler cephesindeki yansımalarına ilişkin olarak Ali, ilk başlarda yapamayız dedikleri işlemleri yaptıklarını ve bunun yarattı̆̆ı heyecanı vurgulamıştır. "ilk başta fazla heyecanlandık. Yapamayız, yapamayız dedik ama ondan sonra yaptık. Bütün her yeri kazdık çıkmadı. En sonunda hiç burada olmaz dediğimiz yerlerden çıktı."(Ali)

\section{Farklı düşünceye saygı duyma alt teması}

Farklı düşünceye saygı duyma alt teması altında öğrencilerin daha çok akran ilişkilerine karşı bakış açılarını ortaya koydukları bulgular elde edilmiştir. "Bence bu çok güzel bir fikir, çok güzel bir düşünce... Böylelikle hiç dışlanma olmuyor ve gerçekten daha eğlenceli oluyor oyunlar. Böylelikle gerçekten çok eğlendik ve güzel bir şekilde öğrendik. Aklımızda daha çok daha iyi kaldı." (Tuna) Burada Tuna'nın ifadesinde geçen "Hiç dışlanma olmuyor." cümlesinin önemli bir bulgu olduğu düşünülmektedir. Farklı düşünceye duyulan saygının estetik öğretimi için önemli olduğu düşünülmektedir. Farklı düşünceye saygı geliştirmeyi yaşam pratiği haline getirmiş çocuklar, çevrelerine eleştirel gözle bakabildikleri gibi kendilerine yöneltilen eleştirilere de açık olurlar. Bu aynı zamanda çocukların eleştiren olarak düzeyli davranış geliştirmelerine de olanak sağlamaktadır. Öğrencilerin grup olarak çalıştııılmalarının alt amaçlarında eleştirel düşünme becerileri kazandırmak yatmaktadır. Nitekim uygulama sonuçlarına yansıyan ifadeler de bu yöndedir. Öğrenciler bir taraftan kendilerini diğer taraftan grup arkadaşlarını rahatça eleştirebilmektedirler.

“Herkesin fikirleri birbiriyle farklı oluyor. Hani aynı fikir hiç çıkmadı. Bizde fikir aynı çıkmıyor. İnsanlar da hep farklı farklı çıkıyor. Çünkü her insanın bir konuya bakma açısı farklı. Bize de böyle oldu. Biz de herkesin fikrini aldık yani iyi de yazsa kötü de yazsa herkesin fikrini olduğu gibi yazdık. Cidden çok güzel bir şiir çıktı. Biz toplu olarak yazmasaydık, bir kişi yazsaydı, diğer arkadaşlarımız şiiri daha sıradan bulacaktı. Fakat farklı farklı düşünceler bir araya gelince çok daha sıra dışı, farklı bir şey ortaya çıkmış oldu. Bu da bizi çok mutlu etti. Ayrıca yine grup çalışmasıyla ilgili pratik yapmış olduk. Yani çok da iyi yorumlar aldık. Bu beni böyle mutlu etti." (Zafer)

Özden'e (2014, s. 160) göre eleştirel düşünme bağımsız olmayı gerektirir. Dolayısıyla eleştirel düşünme hiçbir önyargıyla bağdaşmaz ve bireyde özgüveni geliştirir. Tuna uygulamaların kendisine hem mutluluk verdiğini hem de kendine güvenini arttırdığını vurgulamıştır. "Bu hem bana daha çok umut verdi hem daha çok kendime güvendim. Özgüvenim arttı ve arkadaşlarım sevgim yani arkadaşlarımla olan bağım daha çok gelişti."(Tuna) Eleştirel düşünme, düşünceleri destekler delilleri ve nedenleri dikkate almayı gerektirir. Bu doğrultuda eleştirel düşünen kişi kendi düşünceleriyle farklı düşünceleri gözden geçirir ve alması gerekenleri alarak düşüncelerini zenginleştirir (Özden, 2014, s. 160). Aşağıdaki paragrafta belirtilen Zafer'in uygulama sonrasında yaptığı durum değerlendirmesi, durumdan çıkardığı sonuç ve son olarak arkadaşlarına yönelik geliştirdiği iyi tutum; yukarıda Özden'in "eleştirel düşünen kişi kendi düşünceleriyle farklı düşünceleri gözden geçirir ve alması gerekenleri alarak düşüncelerini zenginleştirir" durumunu açıklar nitelikte olduğu düşünülmektedir.

“...Ama onların fikri daha farklıymış ve biz bunu fark edemedik. Zor bir şey seçmişlerdi. Ee hepsinin altı dümdüzken bir tanesinin altı çıkıntılı olduğu için onu farklı sürmüşler. Bu da değişik bir fikirdi. Benim açıkçası en zorlandığım yer bakır olan yer oldu. Çok benzeyen araçlar vardı. Ama diğer arkadaşlarımız çok iyi bulmuşlar. Onları tebrik ediyorum. Biz de farklı bilgiler öne sürdük, hepsi birbirinden farklıydı ve değişik bilgiler öğrenmiş olduk." (Zafer) Grupça yaşanılan probleme ve o problem karşısında gelişen duruma değinen Zafer grup anlaşmazlıklarına değinmiştir. Fakat sonuçta her derste ortak noktada buluşulduğuna vurgu yapmıştır.

“Bizim için olumsuz yönleri sadece biraz tartışma oldu. Ama o da önemsiz. Zaten grup olmanın amacı bu: Tartışma olmadan bir ortak karara varmak. Olumsuz yönleri olarak kargaşa çıkıyor kalabalık gruplarla yaptığımızda ama sorunu her zaman çözebiliyoruz. Zaten bunun iyi yanı bu. Her etkinlikte bir sorun çıkıyor, çıkar veya yaptığımız işlerde sorun çıkabilir." (Zafer)

Farklı düşüncelere saygı alt teması aynı zamanda da işbirliği ve dayanışma kodlarını da kapsamaktadır. Özellikle uygulamalarda zorlansa da katılımda oldukça gönüllü olan özel gereksinimli öğrenci Nuray, ilk uygulamalarda arkadaşları tarafından dışlandığı yönündeki fikrinin aksine onlardan aldığı desteği vurgulamıştır. "Nereye basacağımı bilemiyordum fark edemedim bir türlü. Sonra arkadaşlarım, grubum yardım etti bana. Hangi tarafa basacağımı gösterdiler. Çok fazla eğlendim. Özellikle üstümün kirlenmesi ve boyalar her yerime gelmesi çok komikti. Arkadaşlarımın bazıları zaten her yerime boya sürmeyi çok iyi becerdi." (Nuray)

\section{Öneri Sunma alt teması}

Öneri sunma teması, AHEE’nin temel unsurlarından biri olan öz farkındalık telkini ve dolaylı olarak kendine güven konusunu içermesi nedeniyle üzerinde durulması gereken bir alt tema olduğu düşünülmektedir. Bu, bir bakıma öğrencilerin uygulamalar aracılı̆̆ıyla gerçekleştirdikleri deneyimlere göre yaptıkları çıkarsamaları içermektedir. Bu bağlamda öğrencilerin bazı uygulamalar içinde kendilerine eleştirel bir bakış açısıyla sabırlı olmak konusunda öneride bulduklarına rastlanmıştır. "Olumsuz yönleri bazen pes ettik ama bu kendimiz için olumsuz yönlerimiz. Bazen oturup düşünmemiz gerekiyor, niye bu kadar sabırsızım. Sabırlı olmak bazen elimizde olmayabiliyor. Ama biz sabırsızlıkla savaşıp sabırlı olmayı öğrenmeliyiz." (Zafer)

Öğrencilerin bazıları ise kullanılan malzeme ve mekân konusunda önerilerini sunmuşlardır. Turan, baskı uygulamasında yapılan zeminin düz olmasını önermiştir. Melda ise renkli benekler adlı derste eldiven kullanmak yerine direkt elle uygulamanın daha iyi 
olacağını vurgulamıştır. "Ama zemin daha düz olsaydı belki şu an üstümde giydiğim tişörtüm daha güzel olurdu.” (Turan)“Ama ben bir dahakine eldivensiz yapmayı daha çok isterim böyle direkt." (Melda)

\section{Kültürel İfade Temasına ilişskin Bulgular}

AHEE ile yapılandırılan uygulamalarla gerçekleşen Görsel Sanatlar Dersi'ndeki uygulamalara dönük verilerde elde edilen kültürel ifade teması ve bu temayı oluşturan alt temalar ve kodlar çerçevesinde irdelenmiştir. Kültürel ifade temasını oluşturan alt tema ve kodlar Şekil 4.' te verilmiştir.

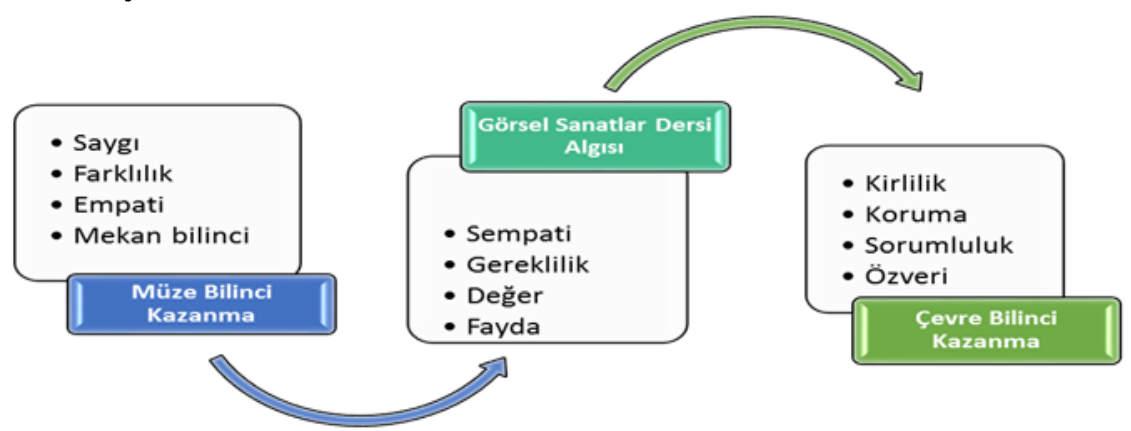

Şekil 4. Kültürel ifade temasına ilişkin alt temalar ve kodlar

\section{Müze bilinci kazanma alt teması}

Kültürel ifade temasının kapsamında bulunan müze bilinci alt teması, Müzemi Oluşturuyorum adlı ders uygulamasından yansıyan verilerden oluşturulmuştur. Araştırmada diğer derslerde olduğu gibi müzemi oluşturuyorum adlı derste de öğrencilerin tüm süreci işbirliği içinde geçirmelerine dayalı olarak yapılandırılmıştır. Dolayısıyla mevcut duruma çözüm getirmek için grupça çalışmaları ve grupça düşünmeleri sağlanmıştır. Açıkgöz'e göre (2014, s. 172) grup çalışmaları sırasında öğrenciler tek başlarına başaramayacakları soru sorma, açıklama yapma, eleştirme, örnek verme gibi çok önemli öğrenme yaşantılarını başka biriyle etkileşime geçerek başarma fırsatı bulurlar. Bu bağlamda grup çalışmalarının hem sürece hem de sonuca olumlu katkı sağladığı düşünülmektedir.

Grup çalışması olarak yapılandırılan bu derste rehberli keşif yöntemi benimsenmiştir. Bazı araştırmacılar bu yöntemi, deney yöntemi olarak da adlandırmaktadırlar. Rehberli keşifteki fark, öğrencilerin başarılı olmalarını sağlamak amacıyla eğitmenin zaman zaman duruma müdahale etmesidir. Rehberlik olmadan, öğrencilerin yanlış bilgi veya beceri öğrenme riski altında olacakları düşünülmektedir (Gilbertson vd. 2005, s. 129). Bu modele göre öğrenci hazır bilgiyi kullanmak yerine bilgiyi keşfederek öğrenmektedirler. Açıkgöz'e (2014, s. 75) göre keşfederek öğrenmesi amaçlanan öğrenciler için öğretmen, bilgiyi sunarken öğrencinin anlayarak öğrenmesini önceler. Öğrenci ise öğrenme malzemesini içselleştirir ve onu ezberlemeden, anlamlı olarak öğrenir. Müzemi oluşturuyorum dersinin uygulama parçası olan kazı çalışması aracılığıyla öğrencilerin arkeologlara, müzelere ve müze çalışanlarına karşı farklı bir bakış açısı geliştirdikleri saptanmıştır. Daha çok, yapılan işin önemi konusunda oluşan farkındalık şeklinde yansımıştır. "Hem o eşyaları bulmak için hem de onları anlatmak için bir sürü zaman yapıyor. Zaman, zaman gerekmiş ona. Değer verdiklerini anlarım ve saygıyla dinlerim." (Ali) Bu yargı diğer odak öğrencilerde de anlamlı düzeydedir.

Araştırmada öğrencilerin alışılagelmiş gezi programlarıyla müzelere götürülmeleri gibi bir yol tercih edilmemiştir. Zafer'in pasif bir katılım örneği olabilecek deneyiminde, müzenin sadece güzel yapıtların olduğu ve gezip çıkılan bir yer olarak adlandırıldığı vurgulanmıştır. "Şimdi müzeye gittiğimizde her şey hazır, orda görüyoruz. Biz insanlar bu kadar zor olduğunu hiç düşünmüyordur. Herkes gitmiştir müzeye, ben de gittim. Çok güzel yapıtlar var. Ne güzel hadi görselini çekelim, diyoruz. Bize kolay geliyor." (Zafer) Zafer'in ifade ettiği şekilde müzeye götürülen öğrenciler bir rehber eşliğinde salt teorik ve monolog bir aktarım süreci geçirmektedirler. Bu durumda çocukların yeterli düzeyde düşünsel süreç geçiremedikleri düşünülmektedir. Uygulama sonucunda Zafer: “...Şimdi anladım ki orayı yerleştirmek için insanlar çok uğraşıyor. Mesela ilk aşama olarak belirledikleri yerleri kazıyorlar ve bir şeyler bulmaya çalışıyorlar. Ama biz zaten ormanda olduğunu biliyorduk ama insanlar hiç bilmiyorlar. Dünyanın her yerinde olabilir bu eserler, onu bilmeden kazıyorlardır." algısındaki farklılığı vurgulamıştır.

Müzemi oluşturuyorum dersinden yaptığı çıkarımları ifade eden Turan'ın ise müzenin oluşum süreçleri ve çalışanlarına ilişkin anlamlı bir bağ kurduğu görülmektedir. Ayrıca Turan müzelerin boş zaman geçirme yeri olamadığı konusunda kazandığı yeni bakış açısını da vurgulamıştır. "Müzeye gittiğimde artık bunların nasıl çıkartıldığını ve ne kadar kaç gün süren bir çalışmanın sonucunda çıktığını ondan önce de bunun yapılırken nasıl yapılıp oraya girdiğini daha çok düşüneceğim. Boş boş gezip gelmektense oradaki her şey hakkında daha iyi bir fikir yürüteceğim. Bunlar artık aklımda bunları öğrendim güzel oldu." (Turan)

\section{Görsel Sanatlar Dersi algısı alt teması}

Kültürel ifade temasını oluşturan bir diğer alt tema ise Görsel Sanatlar Dersi algısıdır. Zafer görsel sanatlar dersinin de diğer dersler kadar önemsenmesi gereken bir ders olduğu yönünde bir farkındalık geliştirdiklerini vurgulamıştır. "Yani resmin de diğer derslerin boyutundan altta görünmeye layık olmadığını da öğrenmiş olduk. Yani resim de tüm dersler gibi önemli bir ders ve bir 
alan. Ee birinin alanı matematik olabileceği, Türkçe olabileceği gibi resim de olabilir. Bu yüzden hiçbir dersi birbirinden ayırmamalıyız. Resimle ilgili daha çok kendimizi geliştirmeliyiz." (Zafer)

Öğrencilerin görsel sanatlar dersine ilişkin yorumları bazen de benzeşimler kurmaları şeklinde olmuştur. Bu bağlamdaki bulgulardan birinde Ali, kuş ile metaforik bir ilişki kurulmuştur. "Dışarıda özgürüz yani şöyle bak, bakarsak bir kuş kafese konulduğunda kapalı alanda olduğunda özgür değil ama dışarıda olduğunda çok özgür. Biz de dışarıda etkinlik yaptığımızda daha özgür oluyoruz ve kısıtlamamız yok. İstediğimiz kadar şey yapabiliyoruz ve çok eğleniyoruz." (Ali)

Uygulamalar sonrası Görsel Sanatlar Dersi için oluşan yaygın kanıdan biri de bu dersin yalnızca kalemle, kâğıtla uygulanabilir bir ders olduğu görüşünün yerini geniş seçeneklerle kurgulanabilir oyun içerikli bir ders olabileceği görüşü almıştır."Ee resim hakkında bir sürü etkinliğin yapılabileceğini düşünüyorum artık. Yani resim sadece eline kalemi alıp boya yapma, resim çizmekten ibaret değil. El sanatları, ne bileyim değişik etkinlikler, oyunlar hatta yarışmalar resmi ifade ediyor. Anlamış olduk ki resimden birçok oyun, eğlence, etkinlik, faaliyet çıkartabileceğimizi burada öğrenmiş olduk. Yani resmi çoğu arkadaşım ve ben sadece elimize kalemi alıp bir konu belirleyip resim çizmek zannediyorduk fakat çok geniş bir açısı varmış." (Zafer) Eskiden olduğu gibi öğrencilerin yeteneklerine göre sınıflanması ve yeteneğin değişmeyen bir özellik olması anlayışının yerini öğrencinin bir konu alanına özgü bilgi ve becerileri öğrenirken diğer yandan öğrenmeyi öğrenmesinin sağlanması anlayışı almıştır (Açıkgöz, 2001, s. 56). Bu bağlamda kendini "yeteneksiz" olarak adlandıran Turan'ın farkına vardığı yeni bilgiyle birlikte somut bir beceri geliştirmiş olduğu için ders ile arasında bir bağ oluşturmaya başladığı görülmektedir. "Çünkü çok yetenekli değilim ama böyle olunca bu dersin eğlenceli bir kısmının olduğunu da gördüm. Daha güzel oldu. Mesela ben asimetrinin ne olduğunu bilmiyordum. Simetriyi de işte tam olarak kafamda yerleştirmemiştim. Bugün bunları tam olarak öğrendim, daha çok pekişti aklımda." (Turan)

Görsel tipte bir çocuk önce yaşantısını görme duyusu ile ilgili yanıyla sınırlar, ikinci gözlem aşamasında yaşantısının bütün olarak bıraktığı izlenim bölümlerini çözümler. Üçüncü aşamada ise bu parçaları yeni bir form için düzenler (Buyurgan ve Buyurgan, 2012, s. 38). Derste kullanılan malzeme bilgisi bağlamında kazanımlarının sorgulandığı öğrencilerden Melda, daha önceki deneyimlerinin de etkisini vurgulayarak bu ders için bir form oluşturma aşamasında malzemenin olanaklarını göz önünde bulundurma bilgisini edindiğini vurgulamıştır. "Bilgi olarak bakarsam malzemelerin yani malzemelerin yapısına göre davranma şeklinin değişmesi gerektiğini öğrendim."(Melda) Sanat eğitiminde duyularla algılama, bilme, öğrenmenin de en önemli bölümünü oluşturur. Bu nedenle çocuklara bu yetilerini nasıl kullanabileceklerinin öğretilmesi hem sanat eğitimi hem de genel eğitim açısından önemlidir ( Buyurgan ve Buyurgan, 2012, s. 38) . Bu algının en aktif olduğu alan olarak duyuşsal öğrenme alanı gösterilebilir. Bu duruma örnek olarak Tuna' nın ifadeleri şöyledir: "Ana ve ara renkleri daha iyi pekiştirdi, bana takım ruhumu daha çok arttırdı. Bilinçli, daha çok bilinçli oldum. Ve bir takım olduğumuz için sorumlulukları üstlenmemiz gerekti. Bazı sorumlulukları üstlenmemiz gerekti." (Tuna)

Öğrencilerin büyük çoğunluğu, özgürce çizerken değişik dünya durumları yaratırlar. Onlar, öykü anlatmaya, bir nesneyi betimlemeye bayılırlar (Kırışoğlu ve Stokrocki, 1997, s.1. 13). Sanat için malzemenin imkânları kullanılarak bir tür yaratma biçimi olduğu söylenebilir. Uygulamalarda çocukların her ders uygulaması için hazırlanan faklı tür ve tipte malzemeyle karşı karşıya kalmaları dolayısıyla, malzemenin olanakları ve oluşum hikâyesine dair bir fikir yürütme sürecine girdiklerine rastlanmıştır. Bu etkinin çocukların malzemeyle ilişkilendirdikleri eylemleri aktardıkları yeni ortamda farklı düzeylerde izler bıraktığı düşünülmektedir. Bu bağlamda renkli beneklerle oyun adlı ders uygulamasında da öğrenciler tarafından vurgulanmıştır.

"Bana çok renklerle ilgili bir merak uyandırdı. Mesela, çok değişik renkler var. Bizim bildiklerimiz ara ve ana renkleri daha çok kullanılıyor. Fakat bunun dışında bir sürü renk var ve karıştırınca cidden çok değişik renkler oluşabiliyor. Mesela, maviyle siyah karıştığında lacivert oluşuyor fakat insanlar sadece en çok bilinen renkleri kullanmışlar. Bunu fark ettim." (Zafer) Özellikle yapılan çalışmalarda rastlanan bir sonuç olan eylemin sürekliliği durumunun da öğrencilerde oluşan bu etkide payının olduğu düşünülmektedir. "Hem hayal gücümüzü geliştirmiş olduk hem de eğlenerek bir etkinlik yaptık. Onun ardından da bu kullandığımız taş veya başka araçlarla betim etkinliği yaptık. Ee ayrıca ellerimizle ve kollarımızla da bu etkinliği yaptık. Ee bu da çok güzeldi yani resim dersinin içinde birçok ders çıkabildiğini buradan görebiliyoruz." (Zafer)

Langer, "Ussal malzemenin görsel formlara dönüştürülmesi” olarak tanımladığı sanatın görsel biçeminin onu us dışına itemeyeceğini belirtir (Kırışoğlu, 2005, s. 100). "Mesela ben böyle bir şey hiç denememiştim. Ellerimi direkt böyle boyaya batırmayı. Ama istiyordum." (Melda) Melda'nın cümlenin sonunda kullandığı "ama istiyordum" ifadesi uygulamadan sonra Langer'in değinmiş olduğu ussal bir malzemenin görsel forma dönüşmesi olarak gerçekleştiği düşünülmektedir. Öğrenme kavramı üzerine yansımalar veri kaynaklarına doğrudan yer verilmiştir. Bu bağlamda odak öğrenciler daha önce bilgi sahibi olmadıkları konulara ilişkin yeni öğrenmelerini gerçekleştirdiklerini vurgulamışlardır. "Mesela nerdeyse sınıfın hepsi asimetriyi bilmiyordu. Sonra da öğrendik, sınıfça yeni bir bilgiye kavuştuk ve yeni bilgiler öğrendim." (Adnan)

Açıkgöz' e göre (2001, s. 57) kavrama işleminde öğrencinin bilgiyi yeniden üretmeye yönlendirilmesi esastır. Öğretmenin rolü, öğrencinin bilgiyi keşfetmesine ve onu özümsemesine yardımcı olmak olmalıdır. Böylece öğrenci sorulunca tekrarladığı başkasına ait bir bilgiye sahip olmak yerine yeni durumlara uyarlayabildiği kendine ait bilgiye sahip olacaktır. Bu bağlamda Tuna, oyun aracılığıyla gerçekleşen öğrenme durumuna ilişkin süreci ve Görsel Sanatlar Dersi'ne karşı oluşan ilgisini vurgulamıştır.

“Fazla unutacağımı sanmam çünkü e her çocuk oyun oynamayı sever ve bu biz şu an hem oyun oynuyoruz hem de öğreniyoruz. Bu gerçekten çok güzel... Ee bu yüzden unutamayacağımız bir sistemdi bence bu yani güzeldi. Artık ana renkler, ara renkler gerçekten çok güzel bir şekilde öğrettiniz. Artık resmi gereğinden daha çok seviyorum." (Tuna)

Bir derse karşı tutum açısından önemli olduğu düşünülen bir olgu da öğrenme ortamlarıdır. Görüşmelere yansıyan ilgi çekici bir detay da öğrencilerin mekân üzerine yaptıkları tespitler olmuştur. Kırışoğlu'na $(2005$, s. 3) göre çoğu yakınmalarımız ders saati 
azlığı, araç ve gereç yetersizliği, kısıtlı çalışma mekânları gibi maddi sorunlarla birlikte; derse gereken önemin verilmemesi, yeteneğin ön plana çıkarılması, öğretimin yalnız yeteneklilere özgü olması gerektiği gibi sanat eğitimini olumsuz yönde etkileyen ilkesel sorunlarla ilgilidir. Bu bağlamda sınıf içi ders ortamına ilişkin tespitlerinde Zafer ortamın sınırlayıcı etkisi üzerine vurgular yapılmıştır. "İçerde işlediğimiz derste zaman çok kayıp oluyor. Sıralar bazıları arkada bazıları önde, dersin yarısı zaten curcunayla geçiyor. Ee tahta yansıyor, perdeyi kapa, perdeyi aç, tahtayı kapa, tahtayı aç, bunaltıcı bir hava camları aç, camları kapa derken dersin yarısı gitmiş oluyor." (Zafer)

Dersle ilgili sıkça vurgulanan kavramlardan birinin de özgürlük olduğu görülmektedir. Bu bağlamda bir ilişki ağı kuran Melda, sınıfta işlenen derslerde ilgi ve motivasyonundaki düşüklüğü vurgularken adaptasyon sorununa da değinmiştir. "Sınıf içinin olumsuz yönleri var bana göre; bir özgür değilsin, her taraf kapalı duvarlar üstüme üstüme geliyor. Bazen yani sınıfın içinde olunca ilham gelmiyor bana. illa ki bir camın önüne gidiyorum. Dışarı bakıyorum, bakıyorum, bakıyorum... Sonra oradan arkadaşlarım diyor, Sen ne yapıyorsun burada? Ondan sonra geri gidiyorum, çizmeye çalışıyorum. Aklımdaki her şey bir anda uçmuş oluyor. Bu, benim kafamı bazen çok karıştırıyor. Ondan sonra mesela, sınıf içindeyken arkadaşlarım çok gürültü yapıyor, dikkatim dağılıyor falan. İç ortamdaki dersler bence çok sıkıcı oluyor. Sınıfta öyle kalıyorsun. Önünde bir defter, boyaların... Belirli bir şekilde, belirli bir konu üstünde her zaman bir ders boyunca..."(Melda)

\section{Çevre bilinci kazanma alt teması}

Öğrencilerin çevre konusunda farkındalık sahibi olmaları önemlidir. Bu uygulamada gözlenmeye çalışılan farkındalıklardan biri de çevre duyarlılığıdır. "Ee bilgide coğrafi bölgelerimizi öğrendik işte, nerde ne var diye onları öğrendik. Bir de çevre bilincim daha çok yükseltti. İkincisi doğal malzemelerle yapılabilecek şeyleri aklımda tuttum ve bunlar hakkında daha çok bilgi edindim.” (Turan) Turan'ın ifade ettiği durum bir bakıma uygulamaya katılan tüm öğrencilerde, çevrelerindeki her bir nesnenin işlev, biçim ve fayda bakımından birbirinden farklı olduğu ve bu farklıların dikkate alınması gerekliliği konusunda farkındalık uyandırdığı düşünülmektedir.

\section{TARTIŞMA}

Araştırmadan elde edilen bulgulara dayalı olarak oluşturulan sonuçlar, görsel ifade, eleştirel ifade ve kültürel ifade temaları bağlamında açıklanmıştır. Uygulamalarda bilinçli olarak birtakım zorluklarla baş başa bırakılan öğrenciler çözüm üretme çabasına girmişlerdir. Karşılaştıkları problemlere çözüm üretirken olasılıklar çerçevesinde düşünmeyi deneyimlemişlerdir. Bu sonuç literatürde (Robbins, 2015, s. 6) ve (Çalışkan ve Karadağ, 2014, s. 65) çalışmalarıyla da desteklenmektedir. Katılımcıların uygulama sürecinde gerek öğretmenleriyle gerekse arkadaşlarıyla iletişim kurma becerilerinde olumlu sonuçlar gözlenmiştir. Etkinliklerden önce genel olarak reddetme tavrı saptanan konularda (cinsiyete göre ret ve yeterliğe göre ret konularında) olumlu sonuçlar kazanılmıştır. Gözlenen durumda etkinlikler sonucunda akran ilişkilerinin olumlu yönde pekiştiğine yönelik çıkarım yapılmıştır. Bu sonuç literatür ile (Açıkgöz, 2001, s. 56) desteklenmektedir.

Yansıtmanın içten dışa ve dıştan içe iki türde yapıldığı tespit edilmiştir. Yeni bilginin inşasında daha çok eski yaşantılara benzeşim kurulduğu görülmüştür. Bu sonuç literatür ile (Açıkgöz, 2014, s. 73) uyumludur. Yansıtma yaparken disiplinler arası ilişki kurma şeklinde bir yönelim gözlenmiştir. Etkinlikler farklı derslerin birbiriyle ilişkilendirilmesine olanak sağlamıştır. Uygulama sürecinde imgesel düzeyde hayal gücünün etkin olarak kullanıldığı görülmüştür. Bu sonuç literatürle ile (Özden, 2014, s. 152) uyumludur. Bunun yanı sıra katılımcıların her uygulama sonrasında uygulamaya ilişkin bir bellek hikâyesi oluşturdukları görülmüştür. "Doğada her şey bir renkmiş." şeklinde oluşan algının karşılaştığı malzemenin salt doğaya ait olması çevre konusunda geliştirdikleri farkındalık ve görsel ilişkilendirme düzeyinde gelişim sağlamıştır. "Kuşun kafesten çıkması" gibi ifadelerle boyaya, toprağa, ağaca, dokunmanın getirdiği duyusal etkiyi göstermiştir. Bu sonuç literatürde yer alan (Açıkgöz, 2014, s. 73) ve (Ugürol,1998, s. 2) aktarımlar ile de uyumludur.

Görsel Sanatlar Dersi algısında olumlu yönde bakış açısı kazanılmasına ilişkin saptamalar elde edilmiştir. Bu bağlamda derse daha farklı yaklaştıklarını belirten öğrencilerden en sık gelen dönüt ise, resim dersinin boyadan kalemden ibaret bir şey olmadığı konusunda edindikleri farkındalık olmuştur. Etkinlikler ilerledikçe yapılan görüşmelerde katılımcılar kendiliğinden neden sonuç düzleminde değerlendirmeler yaptıkları görülmüştür. Bu bağlamda katılımcılar bazen bütünden parçaya bazen de parçadan bütüne ilişkilendirmeler yapmışlardır. Bu sonuçlar literatür ile(Bilir, 1979; San, 1983; Üstündağ, 2002; Artut, 2006: Akt. Ayaydın vd., 2011, s. 173) uyumludur. Bazı temalar tüm katılımcılarda benzer düzeyde gelişirken bilişsel öğrenme düzeyinde, öğrencilerin bireysel farklılıklarının sonuçlara yansıdığı saptanmıştır. Bu sonuçlar literatür ile (İpşiroğlu, 2016, s. 229) uyumludur. Duyuşsal alanda; empati, farkındalık, fayda, heyecan, merak, sorumluluk, stres, tutum, dayanışma, güven, işbirliği, korku, reddetme, sabır, sıkılma, şaşkınlık, zorlanma gibi kodlar elde edilmiştir. Bu sonuç literatür ile (İnan, 2012, s. 2) uyumludur.

Gelişen farkındalık düzeyi daha çok çevre üzerine olmuştur. İlk etkinliklerde doğadan nesnelerin kullanılması komutunu canlı cansız bütün varlıklar üzerinde kullanmışlardır (dalından yaprakları koparmak, yerdeki taşları kazımak vs.). Son etkinliklerin daha özgün bir mekân olan ormanda geçmesine karşın çöp atma, ormana zarar verme gibi yönelimlerden genel olarak uzak durdukları gözlemlenmiştir. Orman canlıları için de (karınca, solucan vs.) oldukça hassas davrandıkları saptanmıştır. Bu sonuç literatür ile (Kırışoğlu, 2014, s. 138) uyumludur. Derslerde dayanışma ön plana çıkmıştır. 
Bütün etkinlikler grup olma esasına dayanmıştır. Katılımcıların her uygulama için uzun uzadıya düşünmeye fırsat bulmadan hızlıca oyuna dahil oldukları bir sistemle öğrenmeleri sağlanmıştır. Bu sürecin başlarında adaptasyon konusunda bocalama yaşadıkları görülmüştür. Bu sonuç literatür ile (Açıkgöz, 2014, s. 172) uyumludur. Katılımcılar aktif eylem içindeyken aynı zamanda ardıl eyleme karar verme durumunda kalmışlardır. Bu döngünün tekrarı ise bir süre sonra yetiyi motor beceri haline getirmelerine olanak sunmuştur. Özellikle renkli beneklerle oyun etkinliğinde bir yandan rakam komutunu dinleyen öğrenciler duyma duyusunu, diğer yandan alana yönelmeyle kinetik hareketi bir diğer yandan da duyduğu rakamı oluşturan rengi bir araya getirecek renkleri düşünmüşlerdir. Bu sonuç literatür ile (Lewis, 1975, s. 9) uyumludur. Dolayısıyla zihinsel süreçlerini eş zamanlı olarak aktif tutmak zorunda bırakılmışlardır. Bu sonuç literatür ile (Gilbertson vd., 2005, s. 6) uyumludur. Bu şekilde eş zamanlı ve çok kanaldan uyaranla öğrenme, çocukları ilk zamanlarda zorlandığı görülse de bir süre sonra seri hareketler haline dönüştüğü gözlenmiştir. Bu sonuç literatür ile (İpşiroğlu, 2016, s. 226) uyumludur.

Araştırmadan elde edilen sonuçlar salt duyuşsal alan üzerine olmakla birlikte bilişsel olarak da GSDÖP doğrultusunda konu seçimi ve uygulama eşleşmesi doğru yapıldığında etkili bir biçimde işlenen konuların çoğunlukla öğrenilebileceği sonucuna ulaşılmıştır. Bu sonuç literatür ile (Arheim,1978: Akt. Kırışoğlu, 2005, s. 192) uyumludur. Malzemenin hazır imkânlarla sunulduğu mekanın sadece sınıf olduğu anlayışının yerini her yerde eğitim söylemini destekleyen bir algı almıştır. Böylece öğreten öğrenen bağlamında standart değerlendirmelerin dışına çıkılmıştır. Bu sonuç literatür ile (Kırışoğlu, 2014, s. 16) uyumludur.

Her farklı yaklaşımda olabileceği gibi AHE'de de sınırlı yanların olduğu gerçeğine değinmek yerinde olacaktır. Öncelikle Açıkgöz'ün (2001, s. 56) belirttiği üzere bu yaklaşımda öğrenciler bağımsız çalışmaya, kendi öğrenmeleriyle ilgili kararlar almaya alışık olmayabilirler. Bu durum öğrenme sürecine direnç olarak yansıyabilmektedir. Bir başka dezavantaj ise çocukların sorumluluk almaktan kaçmaları şeklinde görülmektedir. Bunun yanı sıra akran zorbası olarak nitelenen baskın lider karakterli çocuklarda da durum tam tersine ilerleyebilmektedir. Bu çocuklar, diğer arkadaşlarının özgür alanlarına müdahale, odağı dağıtma, görevi paylaşmama şeklinde yaklaşımlar gösterebilmektedirler. Özür'ün (2010, s. 142) "Sosyal bilgiler dersinde sınıf dışı etkinliklerin öğrenci başarısına etkisi" adlı doktora tezinde, öğretmenlerin sınıf dışı etkinlik uygulamalarına yönelik bakış açılarının genel anlamda olumlu olmadığını ifade edilmektedir. Fakat öğretmenlerin uygulamada karşılaştıkları güçlüklerin, aşılabilir güçlükler olduğu vurgulanmıştır. Dolayısıyla öğretmenlerin, sınıf dışı etkinliklere bakış açılarının değiştirilmesi yanında, yöntem ve teknik zenginliğine doğru gitmeleri gerektiği vurgulanmıştır.

\section{SONUÇ VE ÖNERILER}

Sonuç olarak; uygulama süreciyle geliştirilen bu araştırmanın öğretmenler için faydalı bir kaynak olabileceği düşünülmektedir. Uygulama sürecinde araştırmacının edindiği deneyimler sonucunda AHEE'nin her disiplin için uygulanabilir bir model olduğu görülmüştür. Bu nedenle AHEE ile öğrenme süreçleri geliştirmek isteyen sanat eğitimcilerine fikir vermesi umulmaktadır.

\section{Öneriler}

Bu başlık altında Görsel Sanatlar Dersi öğretmenleri ve alana ilgi duyan araştırmacılara yönelik önerilere değinilmiştir.

- Uygulamalara başlamadan önce saha analizi yapılması önerilmektedir.

- $\quad$ AHE, "Sınıf dışı eğitim, doğada eğitim, duvarsız eğitim vb." isimlerle yaygınlaşmaya başlasa bile Türkiye'de henüz çok yeni bir alandır. Dolayısıyla bir uygulamayı gerçekleştirmek için salt teorik bilginin yetersiz olacağı fikri savunulmaktadır. Ayrıca özellikle sanat eğitiminde AHEE üzerine yapılmış hem yayın hem de çalışmanın çok sınırlı oranda olduğu göz önünde bulundurulmalıdır. Bu çerçevede bir uygulama sürecine başlamadan önce AHE'ye yönelik bir etkinlikte katılımcı olarak bulunulmasının faydalı olacağı düşünülmektedir.

- Bu araştırmada AHE görsel sanatlar öğrenimi için kullanılmıştır. Bu yaklaşıma ilgi duyan eğitimciler farklı konu alanlarında, kendi kazanımlarına yönelik hazırlanmış içeriklerle etkinlikler gerçekleştirebilirler.

- MEB kitap ve kazanımlarında daha fazla yer verilmesinin hem öğretmenler, hem öğrenciler, hem de araştırmacılar açısından kaynak sıkıntısının giderilmesini sağlayabilecektir.

- Sonuçlar olumlu olduğu için bu tip çalışmaların yaygınlaştırılması önerilir.

- AHE hizmet içi eğitime, seminer ya da kongreler de daha çok yer verilmesinin faydalı olacağı öngörülmektedir.

- AHE'nin Lisans programlarının içine entegre edilmesi dolayısıyla farklı disiplinlerde eş zamanlı kullanımına zemin hazırlanması önerilebilir.

Görsel Sanatlar Dersi'nin AHEE ile gerçekleştirilmesinin öğrenene disiplinlerarası kazanımlar sunması ile birlikte uygulama sürecinde karşılaşılması muhtemel sınırlılıkların olduğu da bilinmektedir. Bu bağlamda tartışma bölümünde AHE'nin kullanımına ilişkin sonuçlar literatür çerçevesinde tartışılmıştır. Araştırma "Dışarıda olmak" fikrinin öğrencilerde doğal motivasyon oluşturduğunu göstermiştir. Sonuç olarak; uygulama süreciyle geliştirilen bu araştırmanın öğretmenler için faydalı bir kaynak olabileceği düşünülmektedir. Uygulama sürecinde araştırmacının edindiği deneyimler sonucunda AHE'nin çok disiplinli alanlar için uygulanabilir bir model olduğu görülmüştür. Bu nedenle AHE ile öğrenme süreçleri geliştirmek isteyen sanat eğitimcilerine fikir vermesi umulmaktadır. 


\section{Etik Kurul Onay Bilgileri}

Bu araştırma için Anadolu Üniversitesi Etik Kurulu'ndan, 26.02.2016 kayıt tarihi ve Protokol No:15602 ile Etik Kurul Onay Belgesi alınmıştır.

\section{KAYNAKÇA}

Açıkgöz, K. Ü. (2001). Aktif öğrenme. Tarım Ekonomisi, 6, Sayfa: 52-62.

Açıkgöz, K. Ü. (2014). Aktif öğrenme (13. Baskı). İzmir: Biliş Yayınları.

Adkins, C. ve Simmons, B. (2002). Outdoor, experiential, and environmental education: converging or diverging approaches. ERIC Clearinghouse On Rural Education and Small Schools Charleston wv. 06.12.2016 tarihinde www.eric.ed.gov adresinden alınmıştır.

Akar, H., Gürgür, H. ve Yahşi, Z. (2016). Eğitimde nitel araştırma desenleri. Ankara: Anı Yayıncılık.

Ataizi, M. ve Şimşek, A. (1999). Temel eğitimde durumlu öğrenme ortamlarının düzenlenmesi. Kurgu Dergisi Sayı: 16, Sayfa: 255

Artut, K. (2002). Eğitim Fakülteleri ve ilköğretim öğretmenleri için sanat eğitim kuramları ve yöntemleri. Ankara: Anı Yayıncılık.

Ayaydın, A., Vural, D. ve Tuna, S. (2011). Sanat eğitimi ve görsel sanatlar öğretimi (2.Baskı) Ankara: Pegem Akademi.

Buyurgan, U. ve Buyurgan S. (2012). Sanat eğitimi ve öğretimi (3. Baskı). Ankara: Pegem Akademi.

Creswell, J. W. (2013). Nicel, nitel araştırma deseni ve karma yöntem. (Çev. B. Demir, i. Erdoğan ve Y. Dede). Ankara: Eğiten Kitap.

Çalışkan, N. ve Karadağ, E. (2014). Eğitimde drama teorik temelleri ve uygulama örnekleri (3. Baskı). Ankara: Anı Yayıncılık.

Dewey, J. (2007). Deneyim ve eğitim. (Çev. Sinan Akıllı). Ankara: Odtü Yayıncılık.

Donaldson G. E. and Donaldson, L. E. (1958). Outdoor education: a definition. Journal Of Health, Physical Education and Recreation. 29(May), 17-63.

Ford, P. (1981). Principles and practices of outdoor/environmental education. New York, NY: John Wiley \& Sons.

Ford, P. (1986). Outoor education: definition and philosophy. ED 267941.15.04.2017 tarihinde Http://Eric.Ed.Gov/Erıcdocs/Data/Ericdocs2sql/Content_Storage_01/0000019b/80/2f/2d/E6.Pdf adresinden alınmıştır.

Gilbertson, K., Bates T. and Mclaughlin T. (2005). Outdoor education:methods and strategies. United States: Library Of Congress Cataloging-inPublication Data.

Glesne, C. (2013). Nitel araştırmaya giriş. (2. Baskı). (Çev: A. Ersoy ve P. Yalçınoğlu). Ankara: Anı Yayıncılık.

İnan, H. Z. ( 2012). Okul öncesi eğitimde çağdaş yaklaşımlar Reggi Emilla yaklaşımı ve proje yaklaşımı. Ankara: Anı Yayıncılık.

ipşiroğlu, Z. (2015). Düşünmeyi öğrenme ve öğretme. İstanbul: Say Yayınları.

ipşiroğlu, Z. (2016). Gelin çocuklar birlikte düşünelim. İzmir: Tudem Yayınları.

Kırışoğlu, O. T. ve Stokrocki M. (1997). Ortaöğretim sanat öğretimi. Ankara: Milli Eğitim Geliştirme Projesi.

Kırışoğlu, O. T. (2005). Sanatta eğitim görmek-öğrenmek-yaratmak. Ankara: Pegem Akademi

Kırışoğlu, O.T. (2014). Sanat bir serüven. Ankara: Pegem Akademi.

Lewis, C. (1975). The administration of educations programs. Dubuque, IO: Kendall Hunt Publishing.

M.E.B. (2007). Illköğretim genel müdürlüğü görsel sanatlar dersi (1-8. Sınıflar) öğretim programı ve kılavuzu. Ankara: Devlet Kitapları Müdürlüğü. Merriam, S. B. (2013). Nitel araştırma desen ve uygulama için bir rehber.(Çev. S. Turan). Ankara: Nobel yayıncılık.

Özden, Y. (2014). Öğrenme ve öğretme (12. Baskı). Ankara: Pegem Akademi.

Özen, G. (2010). Maceraya dayalı açık alan eğitimlerinin yönetsel beceriler üzerine etkisinin incelenmesi. (Doktora Tezi), Abant İzzet Baysal Üniversitesi Sosyal Bilimler Enstitüsü, Bolu.

Özür, N. (2010). Sosyal bilgiler dersinde sınıf dışı etkinliklerin öğrenci başarısına etkisi (Doktora Tezi). Gazi Üniversitesi, Eğitim Bilimleri Enstitüsü, Ankara.

Pekşersoy, E. ve Yıldırım, O. (2008). İlköğretim Görsel Sanatlar Dersi 1-8. Sınıflar Öğretmen Kılavuzu Kitabı. (1. Baskı). İstanbul: Devlet Kitapları, Kelebek Matbaacilık.

Priest, S. (1986). Redefining outdoor education: a matter of many relationships. Journal Of Environmental Education, 17 (3), $13-15.126$.

Quay, J. and Seaman, J. (2013). John Dewey and education outdoors: making sense of the 'education situation' through more than a century of progressive reforms. Netherlands: Sense Publishers.

Robbins, A. (2015). Synthesizing the outdoor education literature to create a defination and list of primary objectives. University of Wyoming Wyoming Scholars Respo-sitory. Doctoral Projects, Masters Plan B, and Related Works. 06.12.2016 tarihinde http://repository.uwyo.edu/plan_b/4 adresinden alınmıştır.

Ugürol, Y. (1998). Öğrenen sınıfta öğretmen - öğrenci davranışları.Kuram ve Uygulamada Eğitim Yönetimi Dergisi, Issn 1300-4832. Cilt: 4.

Yazıcı, S. (2005). Yaşayarak öğrenme ve açık alan eğitimleri. HR Dergi Human Resources- İnsan Kaynakları ve Yönetim Dergisi, Haziran 2005.Yavuzer, H. (2000). Resimleriyle çocuk. İstanbul: Remzi Kitapevi.

Yıldırım, A. ve Şimşek, H. (2011). Sosyal Bilimlerde Nitel Araştırma Yöntemleri (8. Baskı). Ankara: Seçkin Yayıncılık, Ankara.

Yurdakul, I., Çolak, C. ve Yaman, N. (2016). Nitel veri analizinde adım adım Nvivo Kullanımı. Ankara: Anı Yayıncılık. 